\title{
Article \\ Sterculic Acid Alters Adhesion Molecules Expression and Extracellular Matrix Compounds to Regulate Migration of Lung Cancer Cells
}

\author{
Rafael Peláez*(D), Rodrigo Ochoa, Ana Pariente, Ángela Villanueva-Martínez, Álvaro Pérez-Sala \\ and Ignacio M. Larráyoz *
}

check for

updates

Citation: Peláez, R.; Ochoa, R.;

Pariente, A.; Villanueva-Martínez, Á.;

Pérez-Sala, Á.; Larráyoz, I.M.

Sterculic Acid Alters Adhesion

Molecules Expression and

Extracellular Matrix Compounds to

Regulate Migration of Lung Cancer

Cells. Cancers 2021, 13, 4370. https://

doi.org/10.3390/cancers13174370

Academic Editor: David Wong

Received: 30 June 2021

Accepted: 25 August 2021

Published: 29 August 2021

Publisher's Note: MDPI stays neutral with regard to jurisdictional claims in published maps and institutional affiliations.

Copyright: (c) 2021 by the authors. Licensee MDPI, Basel, Switzerland. This article is an open access article distributed under the terms and conditions of the Creative Commons Attribution (CC BY) license (https:/ / creativecommons.org/licenses/by/ $4.0 /)$.
Biomarkers and Molecular Signaling Group, Neurodegeneration Area, Center for Biomedical Research of La Rioja (CIBIR), Piqueras 98, 26006 Logroño, Spain; rochoaf@riojasalud.es (R.O.); apariente@riojasalud.es (A.P.); angela.v.m.1997@outlook.es (Á.V.-M.); aperez@riojasalud.es (Á.P.-S.)

* Correspondence: rpelaez@riojasalud.es (R.P.); ilarrayoz@riojasalud.es (I.M.L.);

Tel.: +34-941-278-770 ((ext. 84866) (R.P.) \& (ext. 89878) (I.M.L.))

Simple Summary: Sterculic acid (SA) is a naturally occurring lipid with SCD1 inhibitory activity, but it also modifies many other pathways and underlying gene expression. SCD upregulation has been associated with tumor aggressiveness and progression. Effects of SA treatment over extracellular matrix compounds and adhesion molecule expression have not been described in cancer cells up to now. Our results show that SA induces cell death at high dose, but we also observed that lower concentrations of SA treatments also reduce cell adhesion-migration and modify integrins and extracellular matrix compounds expression.

Abstract: Sterculic acid (SA) is a cyclopropenoid fatty acid isolated from Sterculia foetida seeds. This molecule is a well-known inhibitor of SCD1 enzyme, also known as $\Delta 9$-desaturase, which main function is related to lipid metabolism. However, recent studies have demonstrated that it also modifies many other pathways and the underlying gene expression. SCD overexpression, or up-regulated activity, has been associated with tumor aggressiveness and poor prognosis in many cancer types. Scd1 down-regulation, with different inhibitors or molecular strategies, reduces tumor cell survival and cell proliferation, as well as the chemoresistance associated with cancer stem cell presence. However, SA effects over cancer cell migration and extracellular matrix or adhesion molecules have not been described in cancer cells up to now. We used different migration assays and qPCR gene expression analysis to evaluate the effects of SA treatment in cancer cells. The results reveal that SA induces tumoral cell death at high doses, but we also observed that lower SA-treatments induce cell adhesion-migration capacity reduction as a result of modifications in the expression of genes related to integrins and extracellular matrix compounds. Overall, the functional and transcriptomic findings suggest that SA could represent a new inhibitor activity of epithelial to mesenchymal transition.

Keywords: sterculic acid; extracellular matrix; cell migration; gene expression

\section{Introduction}

Our understanding of the role of the tumor microenvironment (TME) over the recurrence and relapse of cancer has been growing in the last years. The physical properties and composition of the TME generate signals to alter cancer cell proliferation and migration [1,2] and it is thought that the TME could represent a protective niche for tumoral cells during antitumoral therapies [3,4]. The extracellular matrix (ECM) is one of the most relevant elements that compose the TME [5] and it represents a scaffold structure for cells. The ECM is composed of many proteoglycans, glycoproteins and fibrous proteins [6-8] and the organization and composition of this matrix confers each tissue its own characteris- 
tics [8,9]. ECM compounds are modified by tumor cells directly, or in an indirect way, by normal cells to promote cancer cell proliferation, survival or metastasis [10,11].

Collagen is the main structural constituent of the ECM and its aberrant expression, deposition, alignment or cross-linking has been correlated with epithelial-mesenchymal (EMT), tumor metastasis and drug resistance [12]. Collagen fibers and other glycoproteins, such as fibronectin, laminin or elastin, form a mesh that interacts with cells in an adhesion receptor-dependent manner [13,14]. PGs and glycosaminoglycans (GAGs) are also presents in the mesh in the interstitial spaces of the ECM, to capture and store biomolecules and growth factors which regulate cell proliferation, migration and differentiation [15]. The high complexity of the ECM and its alterations promote remarkable changes in matrix properties that are linked to different diseases [16]. Cell-cell and cell-matrix interactions modulate cancer progression and development [17]. The ECM represents a scaffold support for cells, but it also activates signal pathways mediated by membrane receptors that modulate cancer cell hallmarks. Cells are constantly synthesizing, destroying and modifying their ECM. Increased collagen fibers deposition has been also associated with tumor progression and advanced stages of cancer [18]. It has been demonstrated that matrix density blocks antitumoral drug access to the intratumoral cells [19] but it has also been observed that matrix remodeling is associated with tumor progression [20].

Sterculic acid (SA) is a natural lipid present in multiple plant seeds and it is the main component of Sterculia foetia seed oil [21]. This lipid has been described as an inhibitor of the stearoyl-CoA desaturase (SCD) protein and the subsequent transformation of stearic acid to oleic acid [22]. SA treatment reduces monounsaturated fatty acids (MUFAs) levels and has positive effects over pathologies such as glucose tolerance, blood pressure and obesity [23-27]. SCDs overexpression has been observed in many cancer types and it is associated with tumor aggressiveness, poor prognosis and reduction of relapse-free survival of patients of breast cancer and hepatocellular carcinoma (HCC) [28]. SCD1 activity increases membrane MUFAs to promote cell viability [29]. SCD1 inhibition reduces the proliferation of prostate and lung cancer cells [30], and induce cell death [28,31]. Recent studies have demonstrated that SA neutralizes the 7-ketocholesterol (7Kch) induced cytotoxicity in vitro and in vivo models of choroidal neovascularization (CNV) [32]. Molecular mechanisms underlying the SA beneficial effects are still unknown. SA administration modify lipogenic genes such as ACC, FAS, SREBP1a/c [24,33], but it also activate mechanisms against cell injuries such as C/EBP homologous protein (CHOP), glucose-regulated protein, $78 \mathrm{KDa}$ (GRP78) [32] mediated by TLR4 and the activation of many intracellular kinases [34]. However, a transcriptomic analysis of SA treatment of retinal pigmented epithelium (RPE) cells has revealed that this lipid induces a wide range of genomic modifications that affects ECM molecule secretion (COL1A1 and CAV1), cell adhesion (ITG $\alpha 5$ ), metabolism (ACC1, SREBF1, APOE) and angiogenesis (ANGPTL4 and PDGFB) pathways in a SCD1-independent manner [35].

The effects of SA treatment over tumor cells have not been described until now. In the present work we reveal that SA induces tumor cell death in a time- and dose-dependent manner, which is also mediated, at least in part, by a Caspase-3 activation. Our results also demonstrate that lower SA treatments reduce cell wound healing and migration capacity and modify the expression of genes related to cell adhesion an extracellular matrix compounds.

\section{Materials and Methods}

\subsection{Cell Lines and Culture}

A549 and H1299 cells are non-small lung cancer cells obtained from the ATCC (Manassas, VA 20108, USA). A549 is a human lung carcinoma cell line isolated from a 58-year-old male. It presents an epithelial morphology with adherent capability. $\mathrm{H} 1299$ is also a human lung carcinoma cell line isolated from a 43-year-old male. It presents an epithelial morphology with adherent capacity. H1299 and A549 cell lines were cultured in RPMI 1640 medium (Hyclone-Thermo Scientific, Waltham, MA, USA) supplemented with $10 \%$ fetal bovine serum (Invitrogen, Alcobendas, Madrid, Spain) and 1\% penicillin/streptomycin 
(Hyclone-Thermo Scientific). Cells were grown in a $37^{\circ} \mathrm{C}$ environment, with an atmosphere containing $5 \% \mathrm{CO}_{2}$ and $85 \%$ humidity.

\subsection{Cell Treatments}

Cells were seeded at a density of 25,000 cells/well or 50,000 cells/well, in serum and serum free conditions, respectively, in 48-well plates for MTT assays. Serum depleted media was composed of RMPI1640 and 1\% penicillin/streptomycin. A total of 350,000 cells were seeded in 6-well plates for migration and wound healing assays. Cells attached for $24 \mathrm{~h}$ and grew until $100 \%$ confluence. Then, serum-containing media was removed and was changed for serum-free medium for $24 \mathrm{~h}$ before treatment administration. Cells were treated with sterculic acid (SA) solved in DMSO from 0 to $250 \mu \mathrm{M}$ (PPQF, University of Alcalá, Madrid, Spain) for 24 to $72 \mathrm{~h}$.

\subsection{Cell Viability Assay}

Cell viability was analyzed after $24 \mathrm{~h}$ using the 3-(4,5-dimethyl thiazol-2-yl)-5-(3carboxymethoxyphenyl)-2-(4-sulfophenyl)-2H-tetrazolium bromide (MTS) assay (Promega, Madison, WI, USA). Two washes with PBS were made before 1:10 MTS-medium mixture adding. Cell viability was measured after $2 \mathrm{~h}$ of incubation at $37^{\circ} \mathrm{C}$. Results are presented as viability over vehicle-treated cells.

\subsection{Wound Healing Assay}

The monolayer was scratched using a pipette tip and we captured images at the same location at regular intervals $(24 \mathrm{~h})$ during cell migration to close the scratch using a Leica Inverted Microscope and Leica DMI4000B inverted microscope (Leica Microsystems), with N Plan 2.5-20X objectives and equipped with a Leica DFC300 Fx digital camera and using Leica Application Suite V3.3.0. The healed surfaces were further analyzed and quantified using Fiji computing software.

\subsection{Transwell Migration Assay}

Cells were harvested $24 \mathrm{~h}$ after treatment administration and 40,000 cells were plated onto the upper side of 8- $\mu \mathrm{m}$ pore-size Boyden chamber (Corning) previously pre-coated with type I rat tail collagen. Cells were cultured in serum-free media for $2 \mathrm{~h}$ before allowing cell migration towards complete media at $37{ }^{\circ} \mathrm{C}$ for $18-24 \mathrm{~h}$. Cells were fixed in $4 \%$ formaldehyde for $15 \mathrm{~min}$ and washed two times with PBS. The Boyden chamber upper part, where the cells had been seeded, was completely cleaned with cotton swabs before the inserts were stained with $0.5 \%$ crystal violet. Images from the lower part of Boyden chamber were captured using a Leica DMI4000B inverted microscope (Leica Microsystems), with N Plan 2.5-20X objectives and equipped with a Leica DFC300 Fx digital camera and using Leica Application Suite V3.3.0. The number of cells in the lower side of the membrane was counted on images taken from six random fields per transwell.

\subsection{RNA Purification}

TRIzol (Invitrogen, Madrid, Spain) was used in total RNA isolation from cell cultures and it was purified using the RNeasy mini-kit (Qiagen, Valencia, CA, USA). DNase I (Qiagen, Valencia, CA, USA) was used to treat the samples following the manufacturer's instructions.

\subsection{Quantitative Real-Time PCR}

SuperScript III kit (Invitrogen, Madrid, Spain) and random primers were used to reverse-transcribe $1 \mu \mathrm{g}$ of total RNA into first-strand cDNA in a total volume of $20 \mu \mathrm{L}$ according to the manufacturer's instructions. cDNA was mixed with SYBR Green PCR Master Mix (Applied Biosystems, Carlsbad, CA, USA) for quantitative real time polymerase chain reaction (qRT-PCR) using $0.3 \mu \mathrm{M}$ forward and reverse oligonucleotide primers (Table 1). A 7300 Real Time PCR System (Applied Biosystems, Madrid, Spain) was employed in the quantitative measures. Cycling conditions were: an initial denaturation 
at $95{ }^{\circ} \mathrm{C}$ for $10 \mathrm{~min}$, followed by 40 cycles of $95{ }^{\circ} \mathrm{C}$ for $15 \mathrm{~s}$ and $60{ }^{\circ} \mathrm{C}$ for $1 \mathrm{~min}$. At the end, a dissociation curve was implemented from 60 to $95{ }^{\circ} \mathrm{C}$ to validate amplification specificity. Gene expression was calculated using absolute quantification by interpolation into a standard curve. $18 \mathrm{~S}$ gene expression was used as housekeeping.

Table 1. List of primers used in this study.

\begin{tabular}{|c|c|}
\hline Gene Name & Oligonucleotide Sequence \\
\hline ITG $\beta 1$-Fow & AACGGGGTGAATGGAACAGG \\
\hline ITG $\beta 1-R e v$ & ACTTCСТCCGTAAAGCCCAG \\
\hline ITG $\beta 3$-Fow & TTGATGCTTATGGGAAAATCCG \\
\hline ITGß3-Rev & ACCTTGGCCTCAATGCTGAA \\
\hline ITG $\beta 5$-Fow & CAAACTCGCGGAGGAGATGA \\
\hline ITG $\beta 5-R e v$ & AATGCACGGATTGGTCTGGT \\
\hline ITG $\alpha 5$-Fow & TGGCCTTCGGTTTACAGTCC \\
\hline ITG $\alpha 5-R e v$ & GGAGAGCCGAAAGGAAACCA \\
\hline IL-6-Fow & TACCCCCAGGAGAAGATTCC \\
\hline Il-6-Rev & TTTTCTGCCAGTGCCTCTTT \\
\hline ITG $\alpha$ V-Fow & CCAAAGCAAACACCACCCAG \\
\hline ITG $\alpha$ V-Rev & GCTCCAAACCACTGATGGGA \\
\hline TIMP3-Fow & CAAGGGGCTGAACTATCGGT \\
\hline TIMP3-Rev & TCGGTCCAGAGACACTCGTT \\
\hline VIM-Fow & CAGGACTCGGTGGACTTCTC \\
\hline VIM-Rev & TAGTTGGCGAAGCGGTCATT \\
\hline SNAIL-Fow & CTATGCCGCGCTCTTTCCTC \\
\hline SNAIL-Rev & GTAGGGCTGCTGGAAGGTAAA \\
\hline TGF $\beta 1-F o w$ & TTGAGCCGTGGAGGGGAAAT \\
\hline TGF $\beta 1-R e v$ & GCGTTGATGTCCACTTGCAG \\
\hline TWIST1-Fow & ATTCAGACCCTCAAGCTGGC \\
\hline TWIST1-Rev & СATCСТCCAGACCGAGAAGG \\
\hline TWIST2-Fow & AGCAAGAAGTCGAGCGAAGA \\
\hline TWIST2-Rev & CTTGTCAGAGGGCAGCGT \\
\hline ZEB1-Fow & ACGCTTTTCCCATTCTGGCT \\
\hline ZEB1-Rev & TTTGCCGTATCTGTGGTCGT \\
\hline ZEB2-Fow & CCAAGGAGCAGGTAATCGCA \\
\hline ZEB2-Rev & GTGCGAACTGTAGGAACCAGA \\
\hline ACTA2-Fow & CCAACTGGGACGACATGGAA \\
\hline ACTA2-Rev & CAGGGTGGGATGCTCTTCAG \\
\hline CDH1-Fow & GACGCGGACGATGATGTGAA \\
\hline CDH1-Rev & GAAACTCTCTCGGTCCAGCC \\
\hline CDH2-Fow & GCCCAAGACAAAGAGACCCA \\
\hline $\mathrm{CDH} 2-\mathrm{Rev}$ & ACCCAGTCTCTCTTCTGCCT \\
\hline FN1-Fow & TTCCAAGCACAGCCACTTC \\
\hline FN1-Rev & ААСТСТGСТССССАТССТСА \\
\hline NID1-Fow & ACGGGGATGACTTCGTCTCT \\
\hline NID1-Rev & GGGGGTTCACTCGTAGCAAT \\
\hline CD44-Fow & GACATCTACCCCAGCAACCC \\
\hline CD44-Rev & CTGTCTGTGCTGTCGGTGAT \\
\hline 18S-Fow & ATGCTCTTAGCTGAGTGTCCCG \\
\hline 18S-Rev & ATTCCTAGCTGCGGTATCCAGG \\
\hline
\end{tabular}

\subsection{Western Blotting}

Western blot was performed as described previously [36]. Cells were scraped and homogenized in RIPA buffer (Thermo Scientific) containing protease (EDTA-free complete, Roche, Basilea, Switzerland) and phosphatase inhibitors (PhosStop, Roche, Basilea, Switzerland). Homogenates were centrifuged for $30 \mathrm{~min}$ at $15,000 \times g$ and the supernatants collected. Protein concentration was determined by the BCA kit (Pierce, Rockford, IL, USA), with bovine serum albumin as standard, using a spectrophotometer POLARstar Omega, (BMG Labtech, Ortenberg, Germany). Then, $20 \mu \mathrm{g}$ of each sample were mixed with 4x Sample Buffer (Invitrogen, Madrid, Spain) and heated for $10 \mathrm{~min}$ at $70{ }^{\circ} \mathrm{C}$. Sam- 
ples were run on 4-12\% SDS-polyacrylamide gels. SeeBlue plus 2 pre-stained standards (Invitrogen) were used as molecular weight markers. For Western blot analysis, proteins were transferred onto 0.2- $\mu \mathrm{m}$ polyvinylidene difluoride (PVDF) membranes (iBlot system, Invitrogen). For protein identification, membranes were incubated overnight at $4{ }^{\circ} \mathrm{C}$ with a rabbit polyclonal antibody against Caspase-3 (14220S, Cell Signaling, Danvers, MA, USA) at a dilution 1:1000. To standardize the results, a monoclonal IgG anti- $\beta$-Actin antibody (Sigma-Aldridch, Steinheim, Germany) was used at a dilution 1:5000 in the same membranes. To visualize immunoreactivity, membranes were incubated with anti-mouse (715-035-1514, Jackson Immunoreserarch Lab. West Grobe, PA, USA) and anti-rabbit (7074, Cell Signaling) peroxidase-labeled IgGs, and they were developed with a chemiluminescence kit ClarityTM Western ECL (BIO-RAD, Berkeley, CA, USA), and exposed to X-ray films (Amersham Hyperfilm ECL, GE Healthcare, Buckinghamshire, UK).

\subsection{Statistical Analysis}

All data were analyzed with GraphPad Prism 6 software and were considered statistically significant when $p$-value $<0.05$. Values are expressed as means \pm SEM. Non-normal distributed data were evaluated by Mann-Whitney U test. Two-way ANOVA was used for multiple comparisons of independent means with Sidak modification to compare related samples.

\section{Results}

3.1. SA Induces Dose-Dependent Cytotoxicity in Cancer Cell Lines in Serum and Serum-Free Conditions

We treated cells with a broad range of SA doses in medium containing $10 \%$ serum, from 24 to $72 \mathrm{~h}$. We observed that both cell lines did not present cell cytotoxicity as a result of SA treatments at concentrations lower than $150 \mu \mathrm{M}$ (Figure 1). However, we detected cell cytotoxicity in prolonged treatments at higher concentrations $(200 \mu \mathrm{M}$ and $250 \mu \mathrm{M})$ (Figure S1). Furthermore, A549 cells showed slightly more sensibility than H1299 to SA treatments (Figure S1A,B). This increased effect was also observed in the non-tumorigenic human bronchial epithelial cell line, NL20 (Figure S2A).

In order to understand the cellular effects of SA without the interference of lipids of serum, we tested the hypothesis of a delayed effect of SA in serum using MTS assay in serum-free conditions. Figure 2 shows that low SA concentrations have no significant effects over cell viability, and only $100 \mu \mathrm{M}$ SA presented clear cytotoxic effects in these cell lines. We could also observe that H1299 cell line showed a less stable response (Figure 2B) but more sensibility to SA treatments with low doses while A549 cell line is more resistant. In the non-tumorigenic cell line NL20, we also observed an intense cytotoxicity at high dose treatments in serum supplemented media (Figure S2A), while we detected a significant cytotoxicity at low doses around the $60 \%$ of the control cells in serum-free media (Figure S2B). Western blot analysis revealed that SA-induced cytotoxicity is associated with Caspase- 3 activation in long term and high doses treatments (Figure 3B), while short term and lower doses did not show activation of this pro-apoptotic signaling (Figure 3A,B). 
A
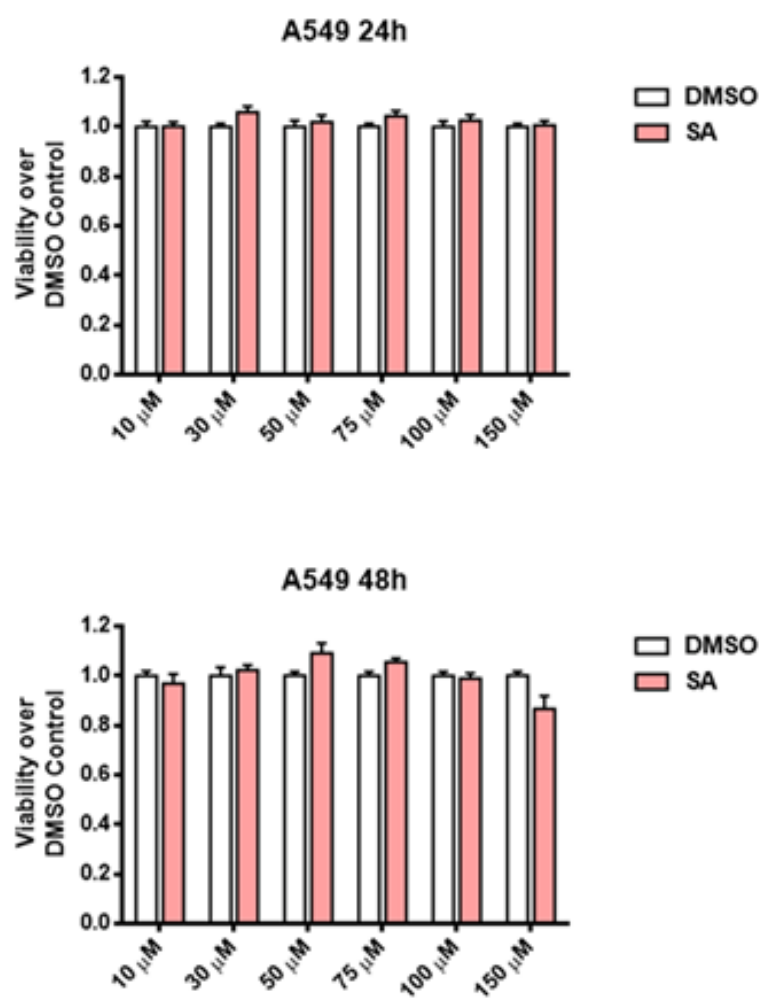

A549 72h

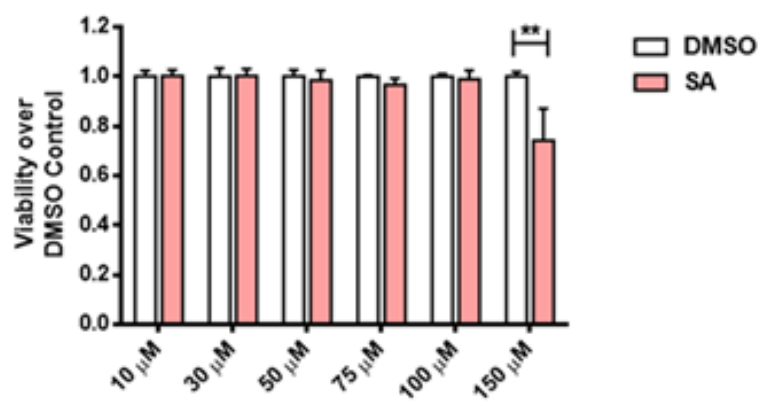

B

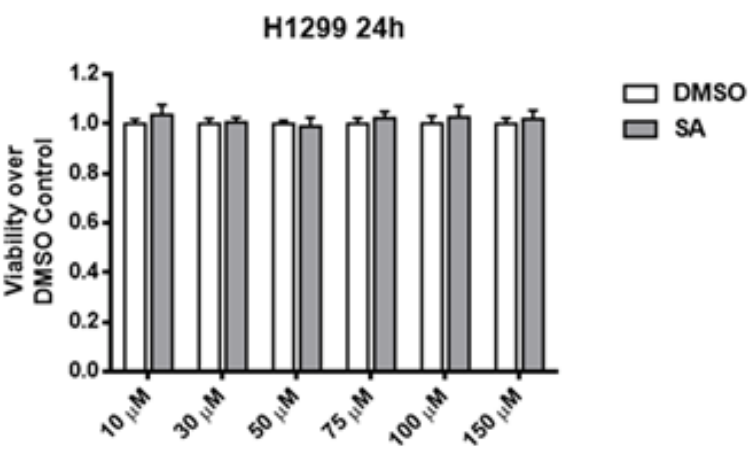

H1299 48h

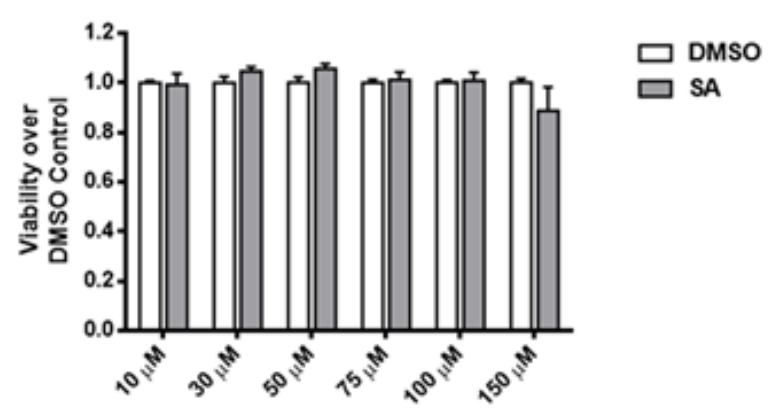

H1299 72h

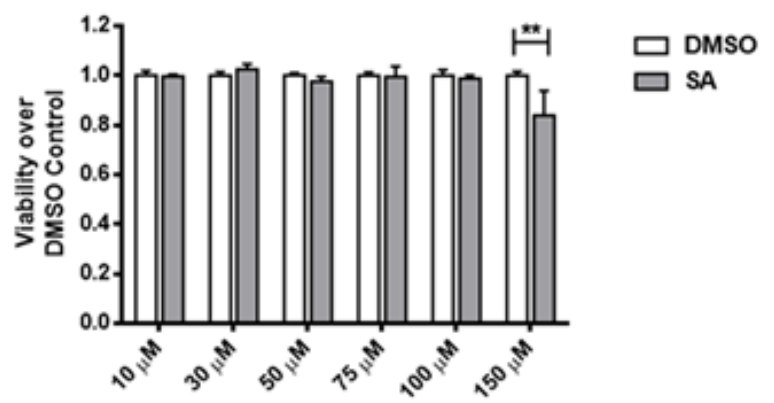

Figure 1. Sterculic acid induces cell death in a dose-time dependent manner in lung cancer cells cultured in $10 \%$ serumsupplemented medium. Cell viability after SA treatment $(10-150 \mu \mathrm{M})$ was measured by MTS method. (A) Cell viability over DMSO control of A549 cells. White bars correspond to cells treated with vehicle (DMSO) while pink bars correspond to cells treated with SA (10-150 $\mu$ M). (B). Cell viability over DMSO control of H1299 cells. White bars correspond to cells treated vehicle (DMSO) while grey bars correspond to cells treated with SA $(10-150 \mu \mathrm{M})$. Data represented mean \pm SEM of 48-well plates of at least three different experiments. ${ }^{* *} p<0.01$. 
A

A549 24h

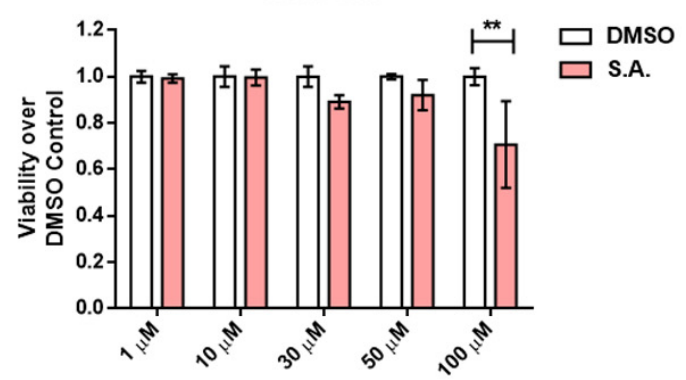

A549 48h

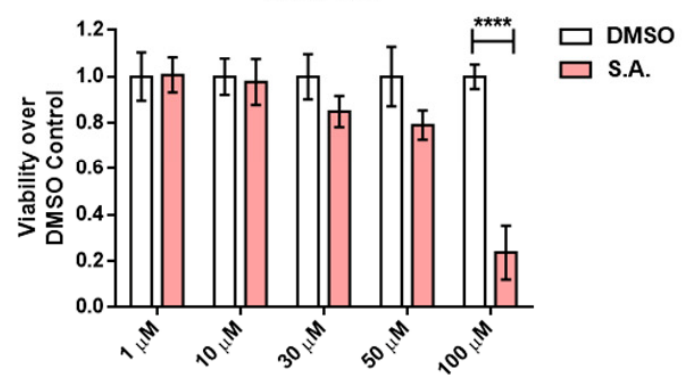

A549 72h

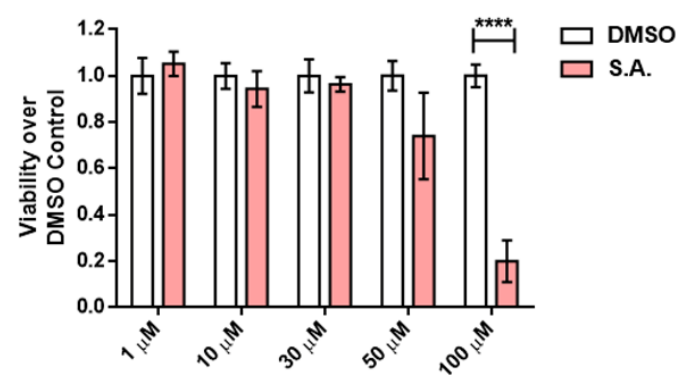

B
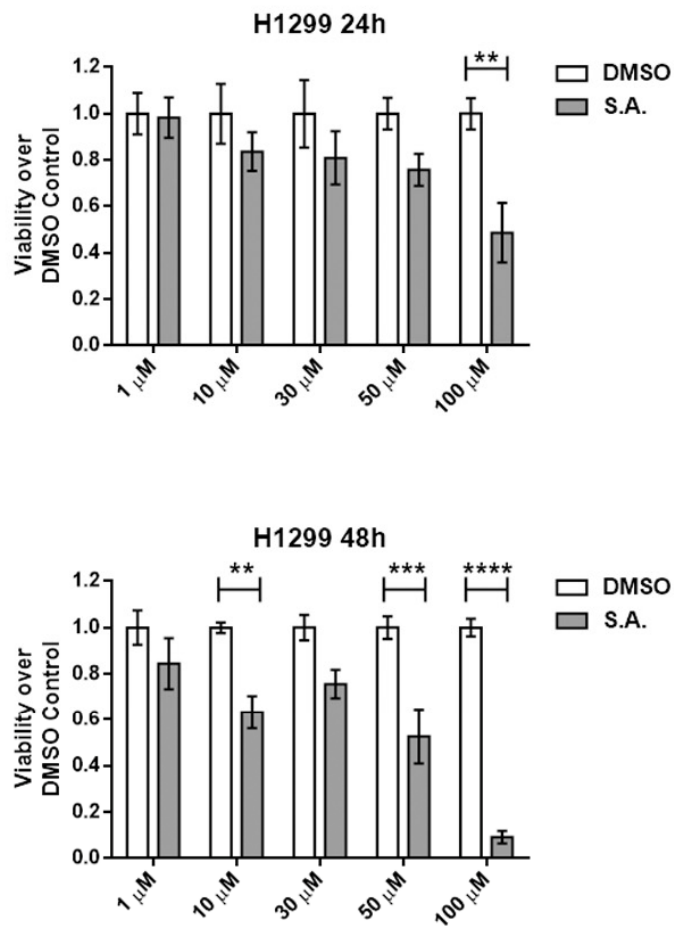

H1299 72h

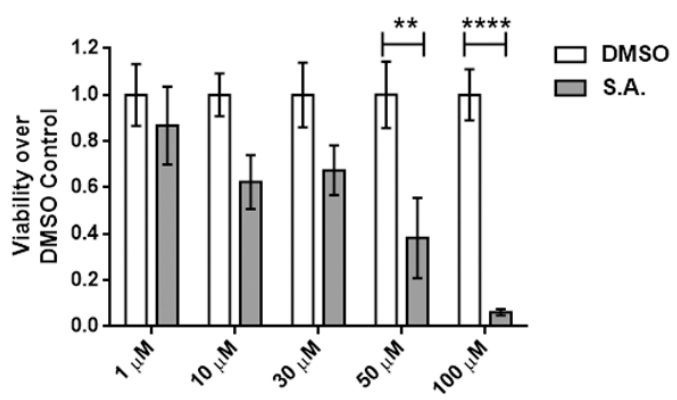

Figure 2. Sterculic acid induces cell death in a dose-time dependent manner in lung cancer cells cultured in serum-free medium. Cell viability after SA treatment (1-100 $\mu \mathrm{M})$ was measured by MTS method. (A) Cell viability over DMSO control of A549 cells. White bars correspond to cells treated with vehicle (DMSO), while pink bars correspond to cells treated with SA (1-100 $\mu \mathrm{M})$. (B) Cell viability over DMSO control of H1299 cells. White bars correspond to cells treated vehicle (DMSO) while grey bars correspond to cells treated with SA $(1-100 \mu \mathrm{M})$. Data represented mean \pm SEM of 48-well plates of at least three different experiments. ${ }^{* *} p<0.01,{ }^{* * *} p<0.001,{ }^{* * * *} p<0.0001$. 
A

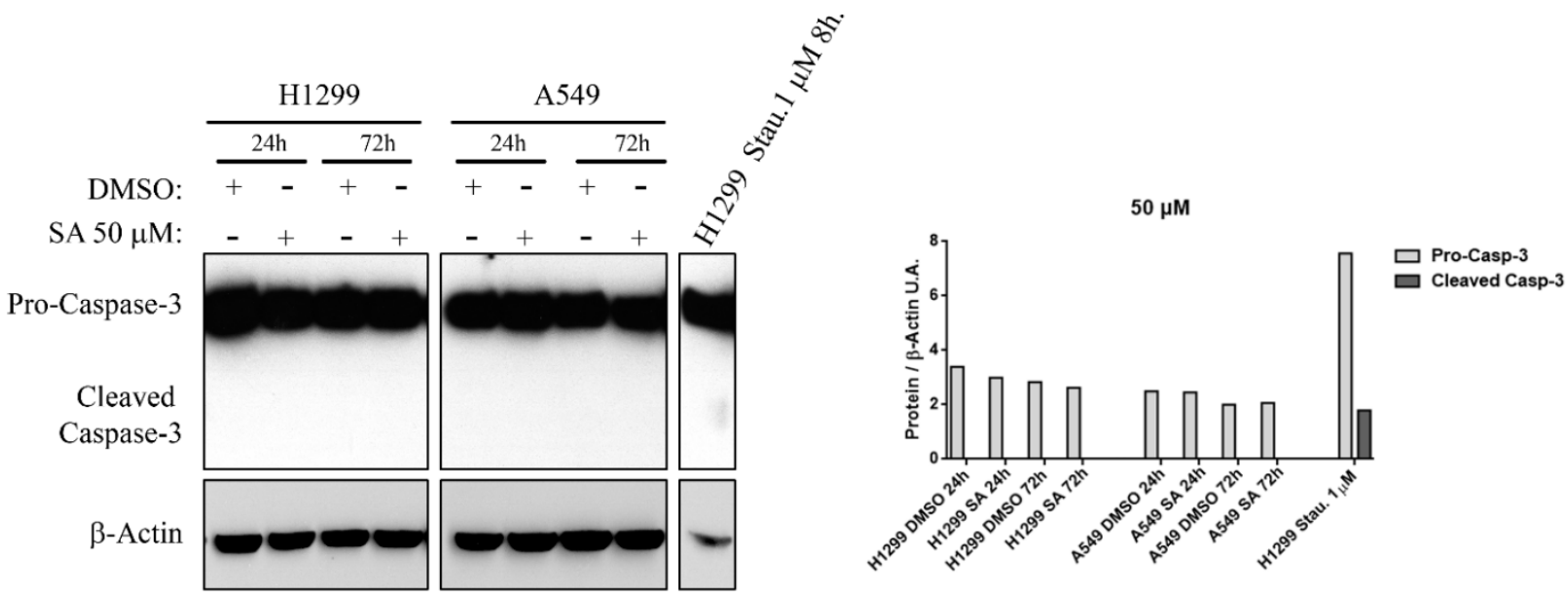

B

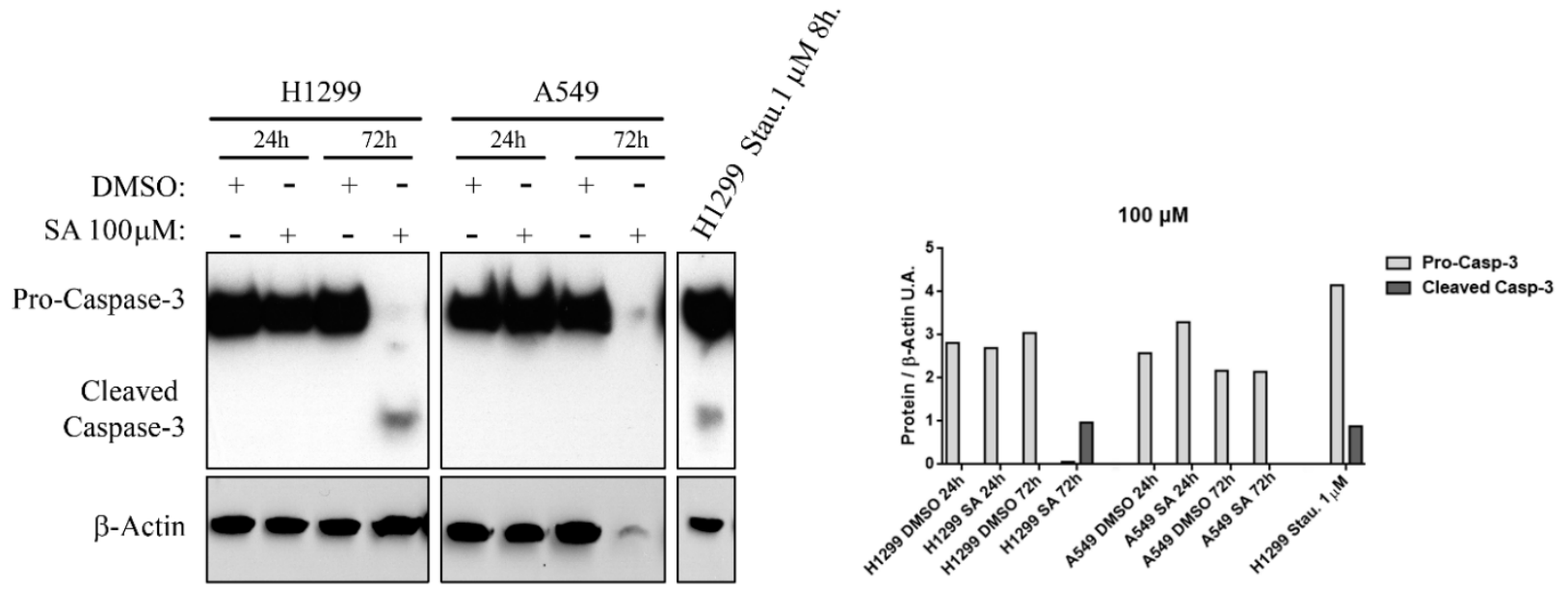

Figure 3. Caspase-3 apoptotic pathway participates in SA-induced cell death. Representative Western blot of Caspase-3 activation in protein extracts of H1299 and A549 cell lines and quantification of Western blot signal intensity (right graphics). Values represents the Pro-Caspase- 3 or Cleaved Caspase- 3 over $\beta$-Actin signal in UA. Staurosporine $1 \mu \mathrm{M}$ treatment in $\mathrm{H} 1299$ for $8 \mathrm{~h}$ was used as positive control of Caspase- 3 cleavage and apoptosis activation. (A) Caspase-3 levels after 24 and $72 \mathrm{~h}$ of $50 \mu \mathrm{M}$ SA treatments. (B) Caspase-3 levels after at 24 and $72 \mathrm{~h}$ of $100 \mu \mathrm{M}$ SA treatments.

\subsection{SA Reduces Cell Motility}

Previous studies in retinal cells have demonstrated that low SA treatments promote the induction of transcriptional changes in multiple cellular pathways, and this could represent a new possible strategy against tumor cells [35]. We evaluated the effects of low dose treatments $(1 \mu \mathrm{M}, 10 \mu \mathrm{M}$ and $30 \mu \mathrm{M})$ in cell migration capacity using a wound healing assay in serum-free media. This a basic assay to evaluate the cellular migration in vitro and it is particularly suitable for studies on the effects of cell-matrix and cell-cell interactions on cell migration.

We observed that both cell lines tried to fill the wound although the migration capacity of A549 cells (Figure 4A) was lower than that of H1299 cells (Figure 4B). Nevertheless, a reduction of A549 cell migration was observed as a result of $30 \mu \mathrm{M} \mathrm{SA}$ treatment. Furthermore, a slight non-significant migration was also observed in A549 for other treatments $(10 \mu \mathrm{M}-72 \mathrm{~h}$ and $30 \mu \mathrm{M}-48 \mathrm{~h}$ ), (Figure $4 \mathrm{~A})$. Interestingly, a prominently SA-induced reduction of cell migration was observed in a time and dose dependent manner in $\mathrm{H} 1299$ cells. At $24 \mathrm{~h}, 30 \mu \mathrm{M}$ SA treatments markedly reduced wound closure while they almost completely abrogated the migration after $72 \mathrm{~h}$ of treatment (Figure $4 \mathrm{~B}$ ). We also observed an important reduction in wound healing closure in $\mathrm{H} 1299$ cells, even with $10 \mu \mathrm{M}$ treatments. 
A
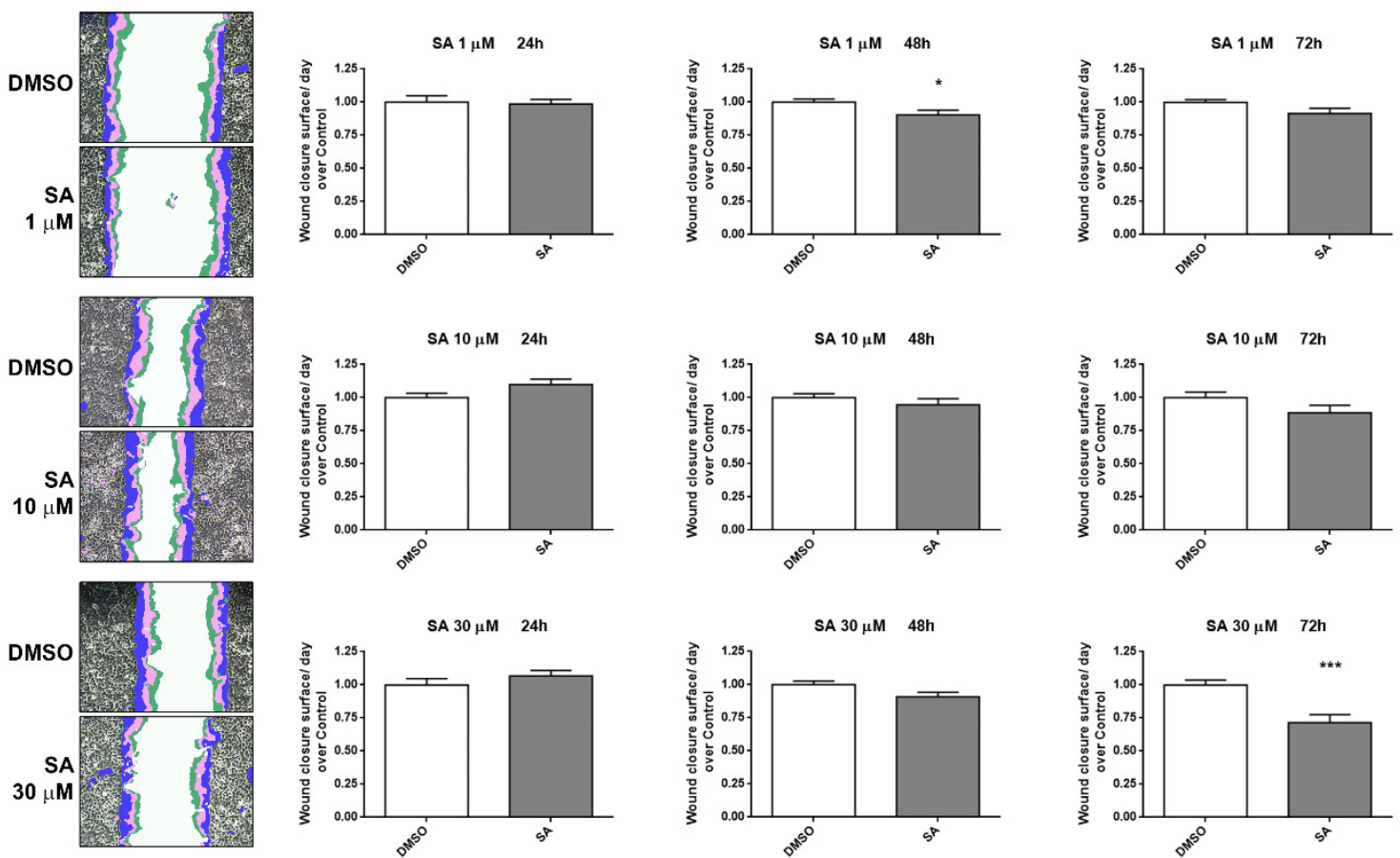

\section{B}
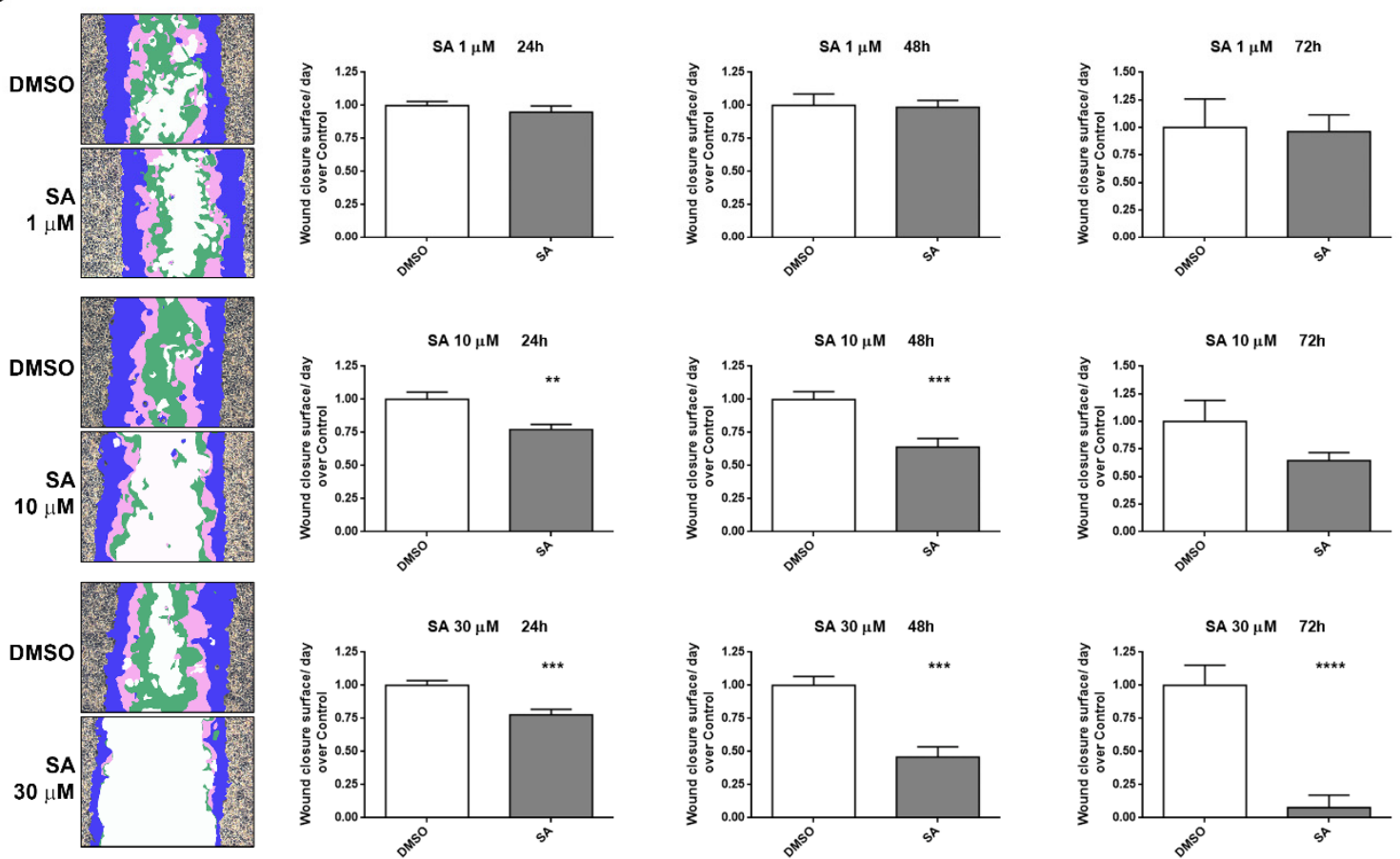

Figure 4. Sterculic acid disturbs wound healing in a dose-dependent manner. A549 (A) and H1299 (B) and cells were treated with SA at concentrations from 1 to $30 \mu \mathrm{M}$ during 24 to $72 \mathrm{~h}$ in serum-free medium. Representative fields of wound healing area per day, where blue regions are the wound's closed surfaces from 0 to $24 \mathrm{~h}$, pink regions are the wound's closed surface from 24 to $48 \mathrm{~h}$, green regions are the wound's closed areas from 48 to $72 \mathrm{~h}$ and white area represents the unclosed scratch region. In the graphs, white bars correspond to vehicle cell treatment (DMSO) while grey bars correspond to cells treated with SA $(1-30 \mu \mathrm{M})$. Data represent mean \pm SEM of closed area per day with respect to its DMSO control from at least two scratches of four independent biological replicates. ${ }^{*} p<0.05,{ }^{* *} p<0.01,{ }^{* * *} p<0.001,{ }^{* * *} p<0.0001$. 
We performed a Boyden chamber assay to specifically evaluate the migration capacity of these cells after SA treatment in serum-free conditions. In accordance with the wound healing assays, H1299 cell line presents a more intense migratory phenotype than A549. A clear cell-spreading morphology was observed on the lower side of the transwell's membrane just after $18 \mathrm{~h}$ of migration, while A549 needed $\geq 24 \mathrm{~h}$. A slight reduction of cell migration was detected in A549 cells when they were treated with 10 and $30 \mu \mathrm{M}$, although differences were not statistically significant (Figure 5A). However, all treatments tested were effective in the reduction of cell migration in H1299 cells (Figure 5B).

A
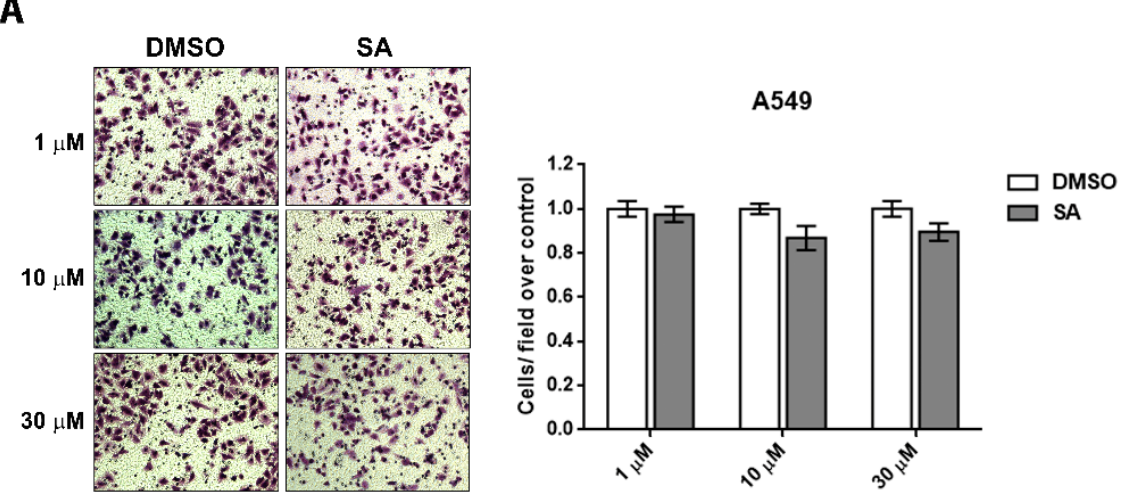

\section{B}
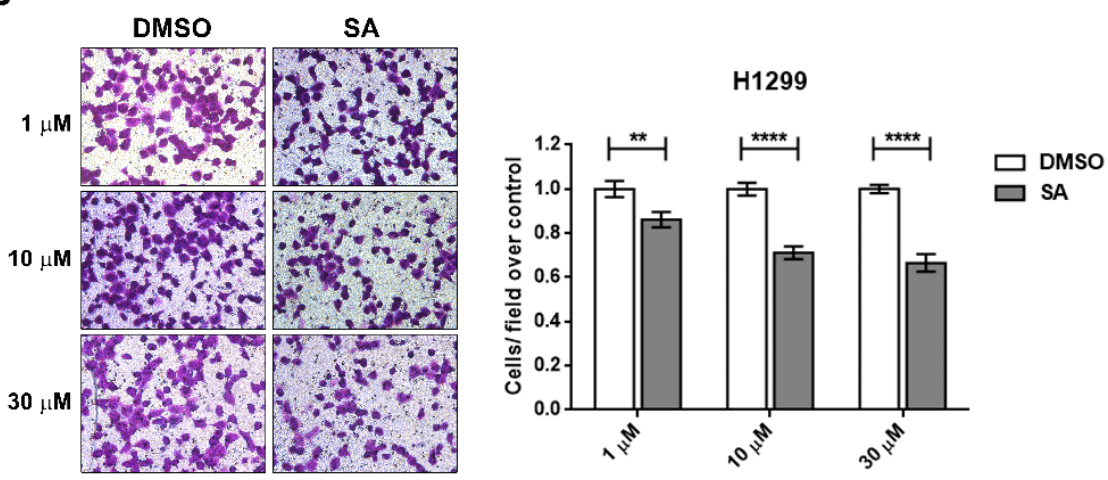

Figure 5. Sterculic acid reduces cell migration capacity in lung cancer cell lines. SA-treated A549 (A) and H1299 (B) cells were allowed to migrate across collagen-coated transwell chambers for $24 \mathrm{~h}$. Representative fields of cell migration are included in figure. Data represents mean $\pm \mathrm{SEM}$ of migrating cells with respect to its DMSO control from at least four independent biological replicates. White bars correspond to cells treated with vehicle (DMSO) while grey bars correspond to cells treated with SA $(1-30 \mu \mathrm{M}){ }^{* *} p<0.01,{ }^{* * * *} p<0.0001$.

\subsection{SA Modifies Expression of Cell Adhesion, Matrix Composition and Remodeling Genes}

The ability of cells to migrate is a result of cell morphology changes, detachment modifications and/or matrix remodeling process, which are usually associated with gene expression modifications and protein activation/inactivation switches. As a consequence of the migrationobserved changes after SA treatment, we decided to evaluate the expression of genes related to cell adhesion, matrix remodeling and ECM compounds. Figure 6 presents down-regulated and up-regulated genes in A549 cells as a result of SA treatment after $24 \mathrm{~h}$ or $72 \mathrm{~h}$. Two genes of the ECM (FNI and NID1) were down-regulated, while adhesion molecules (ITG $\alpha \mathrm{V}$ and ITG $\beta 3$ ) and inflammation-related genes (IL-6) were up-regulated after $24 \mathrm{~h}$ of treatment (Figure 6A). Other genes related to the ECM or cell-ECM interaction were assayed, although no significant expression changes were detected (Figure S3A). 
A
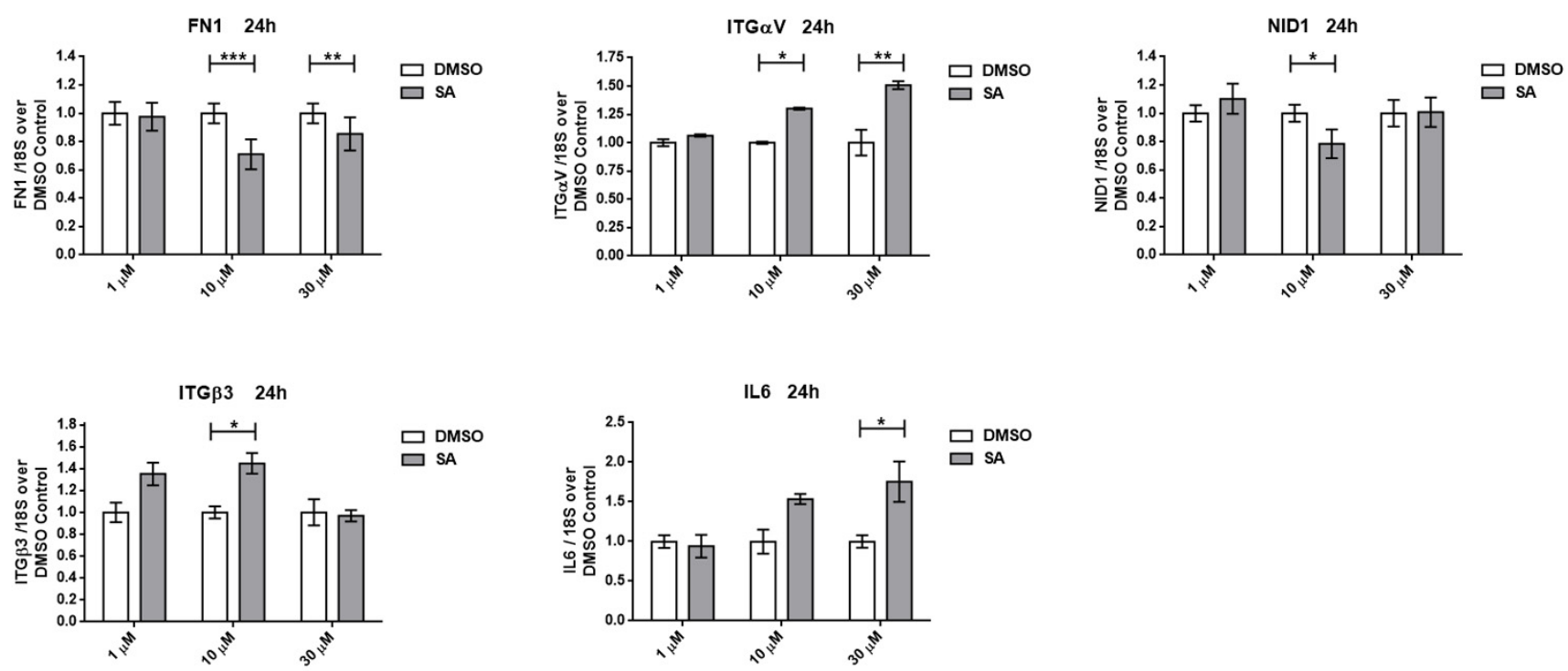

B
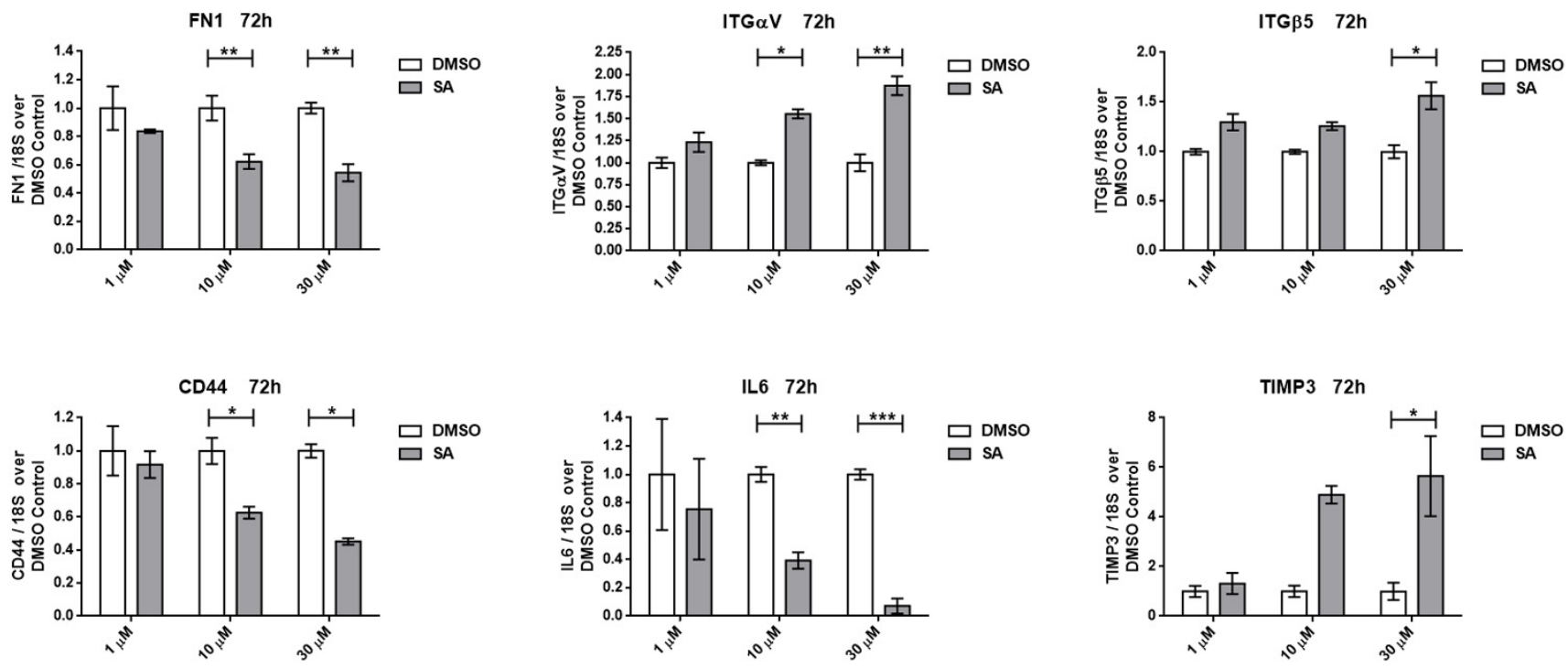

Figure 6. Altered gene expression signature of A549 cells after SA treatments. A broad panel of genes related to cell adhesion and extracellular matrix composition and remodeling was tested. (A) Significant gene expression of control and A549 with SA treated for $24 \mathrm{~h}$. (B) Significant gene expression of control and A549 with SA treated for $72 \mathrm{~h}$. Data represent mean \pm SEM gene expression with respect to the 18S-housekeeping gene of three different experiments. ${ }^{*} p<0.05,{ }^{* *} p<0.01$, $* * * p<0.001$.

In Figure 6B, we show the genes whose expression was altered after SA treatment after $72 \mathrm{~h}$. ECM genes, such as FNI, had reduced expression, whereas TIMP3, a MMP inhibitor gene, was highly up-regulated. Adhesion molecules genes (ITG $\alpha \mathrm{V}$ and ITG $\beta 5$ ) were upregulated, while other adhesion receptors, such as CD44, downregulated their expression.

IL-6 mRNA presented a markedly reduced expression. The same expression switch was detected for ITG $\beta 3$ at $30 \mu \mathrm{M}$ SA treatment, but it was not statistically significant (Figure S4B). Finally, SCD expression was also upregulated in A549 cells after 24 and $72 \mathrm{~h}$ of SA treatments (Figure S5A,B). 
Although SA effects over migration were more prominent in H1299 cell line, it seems that transcriptomic changes are lower at $24 \mathrm{~h}$. We only detected a significant upregulation in the expression of the ITG $\alpha 5$ gene (Figure $7 \mathrm{~A}$ ). When we evaluated gene expression in samples after $72 \mathrm{~h}$ of SA treatment, we observed a decreased expression of ECM members (FN1 and NID1) and adhesion molecules (ITG $\alpha \mathrm{V}$, ITG $\beta 3$ and ITG $\beta 5$ ), mainly at $30 \mu \mathrm{M}$ (Figure 7B). Other genes related to the ECM or cell-ECM interaction were assayed, although no significant expression changes were detected either at $24 \mathrm{~h}$, or $72 \mathrm{~h}$ of SA treatment (Figure S5). Finally, SCD expression was also upregulated in H1299 cells after $72 \mathrm{~h}$ of SA treatments (Figure S6A,B).

A

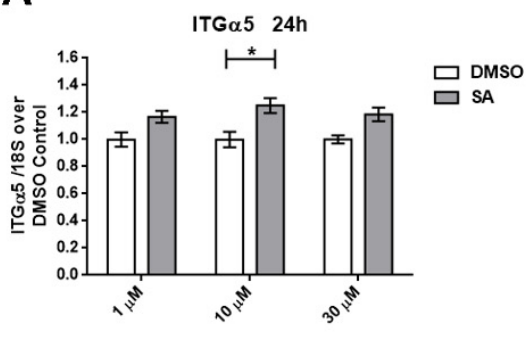

B
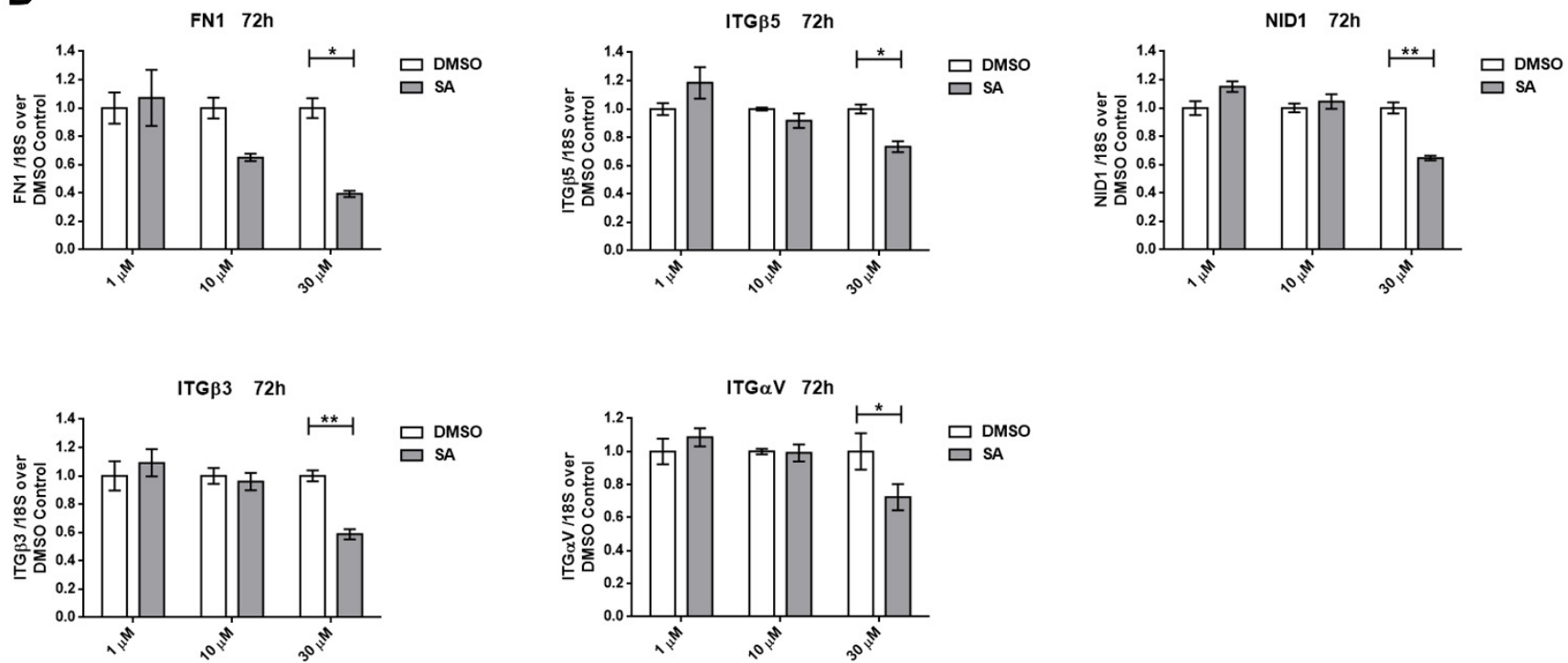

Figure 7. Altered gene expression signature of H1299 cells after SA treatments. A broad panel of genes related to cell adhesion and extracellular matrix composition and remodeling was tested. (A) Significant gene expression of control and A549 with SA treated for $24 \mathrm{~h}$. (B) Significant gene expression of control and H1299 with SA treated for $72 \mathrm{~h}$. Data represent mean \pm SEM gene expression with respect to the $18 \mathrm{~S}$-housekeeping gene of three different experiments. ${ }^{*} p<0.05$, ${ }^{* *} p<0.01$.

Our results showed that SA modified the expression of genes related to cell adhesion, ECM compounds and ECM remodeling which are directly or indirectly associated with EMT, and they could suggest a reversion of EMT as a result of SA treatments. We have evaluated different canonical EMT genes and we found increased expression of mesenchymal markers (ZEB1, TWIST1) after $24 \mathrm{~h}$ of treatment (Figure S5A), and reduction of the epithelial CDH1 gene and its ratio over $\mathrm{CDH} 2$ after $72 \mathrm{~h}$ of SA treatment in A549 cells (Figure S5B). On the other hand, H1299 did not show altered expression of EMT genes after $24 \mathrm{~h}$ (Figure S6A). H1299 cell lines showed ACTA2 mesenchymal gene reduced expression, while the ratio $\mathrm{CDH} 1 / \mathrm{CDH} 2$ was upregulated after $72 \mathrm{~h}$ of SA treatment 
(Figure S6B). All the other evaluated EMT genes (ZEB1, ZEB2, TWIST1, TWIST2, TGF $\beta 1$, $\mathrm{CDH}, \mathrm{CDH} 2$ VIM and SNAIL) did not show altered expression after treatment in both cell lines (Figures S5AB and S6A,B).

\section{Discussion}

Although the antitumoral effects of lipid metabolism inhibition have been widely demonstrated, the effects of SA over cancer cell lines have not been shown until now. Sterculic acid is a lipid described as a stearoyl-CoA desaturase inhibitor, so this molecule could be used as a new lipid metabolism modulator to control de novo lipid synthesis. SCD inhibition, or silencing, reduces cell proliferation in A549 cells [37], whereas it promotes Caspase-3-dependent apoptosis in H1299 cells [38]. Furthermore, it was observed that SCD1 inhibition induces ER stress and the subsequent cell death [39]. Our results demonstrate a low SA cytotoxicity $(150-250 \mu \mathrm{M})$ in NSCLCs, which is increased as a result of serum starvation. This effect is in concordance with other authors that observed an IC50 reduction of SCD1 inhibitors to promote cell death when they reduced serum levels from 10\% to 2\% in A549 and H1299 cells [39]. We also observed this effect in the normal bronchial epithelial cell line NL20. Other SCD1 inhibitors with higher affinity for SCD, such as CAY10566, MF-438 or A939572, require much lower concentrations than SA to induce their cytotoxic effects [28]. These data suggest that SA it not a very potent SCD-1 inhibitor, and therefore may induce its different cellular effects independently of SCD1 inhibition. Our results suggest that SA-induced cell-death is associated with apoptosis induction because Caspase-3 cleavage was detected in H1299 cells exposed to high SA doses $(100 \mu \mathrm{M})$ for a long time. This observation is in concordance with an induced H1299 apoptosis after treatments with the SCD inhibitor CVT-11127 [38]. Caspase-3 cleavage is a central element of the execution-phase of apoptosis, but it can also mediate an alternative pathway activation of pyroptosis [40]. Lipid peroxidation associated to ferroptosis could be an alternative cell-death mechanism, nevertheless Caspase activation has not been described in ferroptosis cell-death [41]. Simultaneous activation of some cell death mechanisms has been already observed [42,43]. We postulate that Caspase-3 activation could be the final step of an alternative/mixed cell-death mechanism, although pyroptosis could not be excluded as an alternative SA-induced cell-death mechanism.

Previously, we performed a genome-wide transcriptome analysis in retinal cells and we observed that many cell pathways related to extracellular matrix, cell adhesion and actin-cytoskeleton reorganization altered after SA treatment [35]. Furthermore, an SCD1independent change was observed in the expression of adhesion and ECM genes such as ITG $\alpha 5$, Col1a1, CAV1 [35]. In that work we also detected altered expression of other genes related to: collagen (COL1A1, COL1A2, COL3A1, COL5A2, COL7A1, COL8A1, COL9A1, CO111A1, COL16A1, COL17A1), laminins (LAMA3, LAMC1), thrombospondins (THBS3), fibronectin (FN1), versican (VCAM), cell adhesion (ITGB2, NCAM1, SDC2, CLDN16, CDH1, CDH3, CDH10, CDH15), growth factors (IGFBP3, IGFBP4, IGFBP5, IGFBP8, IGFBP9) and actin-cytoskeleton reorganization (Filamin, Parvin, MLC, MLCP and RHO) [35]. Aramchol, another SCD1 inhibitor, has been recently described as presenting antifibrotic activity independently of SCD1 expression. In hepatic stellate cells (HSCs), Aramchol downregulated ACTA2, COL1a1 and MMP2 expression as well as collagen secretion [44].

Functional studies of cell migration, such as wound healing and Boyden chamber assay, showed that SA treatments reduce tumor cells migration. We also observed that this effect is more prominent in the H1299 cell line. In order to understand the SA-induced migratory modulation, we evaluated the effects of SA treatment over genes related to cell migration and extracellular matrix. Since the baseline expression signature of both cell lines is different, up and down-regulated genes differ between both cell lines [45-47], highlighting the relevance of the genetic background of the cell. For instance, we could not detect expression of TIMP3 and IL-6 in H1299 cells, while both genes presented SA-altered expression in the A549 cell line. CD44 is another example because it is modulated by SA (possibly through p53 signaling) in A549 cells while it is not changed in the H1299 cell 
line (a TP53 deficient cell line) [48]. However, our data showed that the H1299 cell line presented more a prominent migratory response to SA treatments, while A549 cell lines showed the opposite effect (an intense regulation of genes but lower migratory modulation after SA treatments).

Many other genes presented altered gene expression upon SA treatments. For example, we observed that FN1 gene is slightly down-regulated after $24 \mathrm{~h}$, and it is strongly reduced after $72 \mathrm{~h}$ in both cell lines. FN is a glycoprotein involved in cell adhesion, cell motility, wound healing and maintenance of cell shape, but it also participates in the deposition of other ECM compounds [49,50]. Fibronectin has been described as a classical mesenchymal marker [51] and it is up-regulated in many tumors [52,53]. Therefore, the reduced FN expression could contribute to the decreased migration observed after treatment. Incidentally, reduced cell migration has been observed after FN1 genetic depletion in MCF10CA1h [54]. This FN1 down-regulation was also observed in SA-treated retina cells [35].

Fibronectin interacts with $\alpha 5 \beta 1$ integrin to promote cell proliferation in an MAPK/ERKand EGF-dependent manner [55], but it also promotes EMT in a STAT3-dependent manner [56]. However, our data does not show a solidly altered expression of $\alpha 5$ integrin or $\beta 1$ integrin after SA treatments. Fibronectin also interacts with other integrin or adhesion molecules [50]. For instance, integrin $\alpha \mathrm{V} \beta 3$, fibronectin and fibrin form a ternary complex to control invadopodia formation and promote cell proliferation and metastasis [57]. Previously, we demonstrated that $\beta 3$ functional blocking reduces invadopodia formation in A549 and H1299 cells, while TGF- $\beta$ increases invadopodia formation, MMP2 protein and Smad2/3 signaling in H157 NSCLC cells [58]. These data are in concordance with our reduced cell migration and $\beta 3$ downregulation after SA treatment in H1299 cell line. Furthermore, TGF- $\beta$ up-regulates $\beta 3$ integrin expression in NSCLC to promote lymph node metastasis [59] and promotes EMT [60,61]. Combined targeting of TGF- $\beta$ and $\beta 3$ integrin reduces metastasis $[59,60]$. Recently, it has been proposed that $\alpha \mathrm{V} \beta 3$ integrin also induces EMT in a TGF- $\beta$-independent manner in A549 cells. This partial EMT induction promotes cell motility but it does not require E-cadherin (CDH1) absence [62]. This EMT is linked to ZEB1 and it is inhibited by miR200, which suppresses membrane location of $\alpha \mathrm{V} \beta 3$ without effects over $\alpha \mathrm{V}$ or $\beta 3$ integrin intracellular expression [62]. These multiple mechanisms of EMT induction could explain the bi-phasic expression of $\beta 3$ integrin in A549 cells. This integrin is up-regulated at low SA doses at $24 \mathrm{~h}$, while it is down-regulated at high doses and longer times of treatment. Integrin $\beta 3$ is closely related to MMPs [63], TIMPs [64] and other ECM remodeling mechanisms $[65,66]$. TIMP3 is an ADAMs and MMPs inhibitor with tumor suppressor activity. This gene is an inhibitor of angiogenesis and TNF- $\alpha$, but it is also a component of ECM [67] which is associated with cell migration and ECM remodeling in A549 cells and primary NSCLC patients $[68,69]$. TIMP3 presents an opposite relation with ITG $\beta 3$, because it inhibits FAK and $\beta 3$ recruitment to focal adhesions [67]. All these data would be in concordance with our observation of $\beta 3$ integrin reduction in A549 cells, and the reduction in cell migration.

$\alpha \mathrm{V}$ and $\beta 5$ integrins are adhesion molecules related to cancer progression and tumor cell migration and invasion [70]. In concordance with the reduced H1299 migration, we detected low expression of both integrins in $\mathrm{H} 1299$ after SA treatment. Reduced migration was also observed in breast cancer cells after $\alpha \mathrm{V}$ integrin silencing, while integrin overexpression conferred stem-cell-like properties [71]. However, we detected an intense $\alpha \mathrm{V}$ and $\beta 5$ integrin overexpression in SA-treated A549 cells. This result could justify the absence of reduced wound healing assay of A549. Nevertheless, we cannot exclude the possibility of activation of compensatory mechanisms to overcome FN1 deficiency or reduced integrin adhesion/signaling. Bidirectional cell-ECM control has been demonstrated [72], for instance, ZEB1 knockdown up-regulates laminin and $\beta 4$ integrin and down-regulates $\alpha 3$ and $\beta 1$ integrin [73], or compensatory signaling mechanisms were observed after $\beta 3$ integrin silencing $[74,75]$.

NID1 is a basement membrane with prometastasic characteristics, which it is also upregulated in the lung metastasis of breast cancer cells. Its expression correlates with poor 
outcomes [76]. miR-767-3p reduces NID1 expression and inactivates the NID1/PI3K/Akt/ EMT pathway to reduce tumor growth in NSCLC [77]. NID1 down-regulation was detected after $30 \mu \mathrm{M}$ SA treatment in H1299 cells, while the A549 cell line did not modify its NID1 expression. This expression pattern is in agreement with our wound healing results.

CD44 is the main cell surface receptor of hyaluronan (HA), which is associated with the rapid remodeling of the matrix [48]. CD44 is a classic cancer stem cell marker [78] and it is closed related to TGF- $\beta$-induced EMT in the A549 cell line [79]. We detected a strong inhibition of CD44 expression in the A549 cell line after $72 \mathrm{~h}$ of SA treatment, while H1299 kept constant levels of the gene. Since H1299 is a null TP53 cell line and P53 is a CD44 repressor [48], the absence of response to SA treatment was not surprising in this cell context.

IL-6 is a cytokine that has been related to tumor metastasis and EMT through STAT3 signaling [80]. SA has been demonstrated to reduce 7KCh-induced IL-6 levels in retinal cells in a TLR4 and ER-Stress mediated process [32], although SA alone did not alter IL-6 levels [35]. We could not detect IL-6 expression in H1299 cells in concordance with Bihl and co-workers [81]. Molecules with NF-K $\beta$ inhibitory activity reduce IL-6 expression in a STAT3 dependent manner in A549 cells, and they also reduce cell migration, invasion and alter EMT markers [82-84]. Furthermore, TLR4 knockdown reduces IL-6 levels and cell migration of A549 cell by Pi3K/AKT pathway inhibition [85]. Our results showed an increased expression of IL6 at $24 \mathrm{~h}$ and this may explain the lack of effect of SA in wound healing assay, while the decreased levels of IL6 in SA-treated cells at $72 \mathrm{~h}$ reduced wound healing closure. A positive feedback, called IL6 amplifier, associated with the NF-K $\beta$-IL6-STAT3 axis in non-immune cells has been described [86]. IL-6 binding to its receptor (IL-6R) depends on ADAM17 because it forms a soluble receptor (sIL-6R $\alpha$ ) necessary for the pathway signaling [87]. Since TIMP3 is an ADAM17 inhibitor [88], TIPM3 up-regulation in SA-treated cells could be responsible of IL-6 mRNA reduction in A549 SA-treated cells.

SCD up-regulation after SA treatments was observed in both NSCLC cell lines, which had not been observed in our studies in non-tumorigenic MRPE cells [35]. SCD expression is modulated mainly by SREBP- 1 and ChREBP [28,31], although many other pathways can also promote its expression, PPARs; LXR, C/EBP- $\alpha$, NF-Y, SP- $1, \beta$-Catenin, MAPK pathway [31], but some of these factors also downregulate SCD expression [89]. We cannot discard the possibility of a SCD1 overexpression as a result of cellular response to reduced levels of fatty acids (FA). Oleic acid restores the migration of SCD-inhibited breast cancer cell [90] and it is a PTEM/AKT-dependent process in colorectal cancer [91]. However, oleic acid supplementation does not restore the reduced GSK3b / AKT signaling in SCD1-silenced A549 cells [37].

Cell migration and extracellular matrix remodeling are processes closely related to the epithelial-mesenchymal transition. This is a cellular de-differentiation process associated with cancer metastasis, but it is also a normal process during embryonic development and wound healing [92]. Cell adhesion, matrix compounds or cell-microenvironment interaction genes also adapt their expression to the new cellular program and environment $[93,94]$. Our results show that SA modified the expression of genes related to cell adhesion, the ECM and ECM remodeling, and many of these genes are associated with EMT. We have studied the expression levels broad panel transcription factors which are associated with a mesenchymal phenotype (ZEB1, ZEB2, TWIST1, TWIST2, TGF $\beta 1$, CDH2 VIM and SNAIL), as well as the CDH1 epithelial marker. If SA treatment could induce EMT reversion we would expect the increased expression of epithelial markers and reduction of mesenchymal markers. Our results showed that only ACTA2 gene presented a significant reduction of expression in $\mathrm{H} 1299$ cell line after $72 \mathrm{~h}$ of SA treatment, which is in concordance with Bhattacharya and co-workers that observed ACTA2 gene was downregulated after SCD1-inhibition with Aramchol [44]. Furthermore, SCD1 deficiency has been described to reduce EMT signaling in a GSK3 $\beta$-dependent manner and promote an epithelial phenotype [95]. Nevertheless, we observed a significant reduced expression of the CDH1 epithelial marker in SA-treated A549 cells. This result is in concordance 
with our transcriptomic analysis in mRPE cells [35]. This reduction in CDH1 is consistent with the overexpression of its repressors ZEB1 and ZEB2 [96]. SNAIL also showed a non-significant reduced expression in both cell lines, but we think that this does not compensate for the significant (ZEB1, TWIST1) and non-significant (VIM, CDH2, TWIST2) overexpression of some other mesenchymal markers, which in some cases are downstream elements of the SNAIL signal pathway. As summary, we can exclude that SA promotes a reversion to an epithelial phenotype through the classical alteration in mesenchymal markers. On the contrary, SA induces a reduction in lung cancer cells migration capability as a result of modification in the cell-ECM interaction and compounds.

Intratumoral heterogeneity, subpopulations in cell lines or differential cellular response to treatments could be factors associated with drug-tolerant persistent cells or minimal residual disease (MRD). Detection of robust targets or biomarkers would help to overcome these problems, which are the origin of the poor prognosis and the worse evolution of patients. Single-cell technology and microfluidic devices are new approaches to detect markers or predict a cancer's evolution [97-99]. Analysis of SA-treated cell with these methodologies could help to detect key targets/elements with altered expression in a cellular subpopulation that could be masked by its expression in other cellular subpopulations after treatments. These new methodologies would lead us to develop personalized treatments or predict the evolution and/or response of patients in order to obtain therapies with lower secondary effects as well as more efficient and cheaper.

\section{Conclusions}

In this work we report that SA presents interesting properties over cancer cells. We detected an induced cell cytotoxic effect at high SA doses, while we observed cell motility defects as a result of low SA doses. Molecular analysis revealed a transcriptomic signature switch associated with a reduced migratory capacity, which could be also compatible with ECM remodeling failure. Taken together, our results reveal that SA is a natural lipid with migration inhibitory properties, as a consequence of the altered expression of the ECM and adhesion molecules, which may serve as a co-adjuvant in cancer treatments.

Supplementary Materials: The following are available online at https: / www.mdpi.com/article/10 .3390 / cancers $13174370 /$ s1, Figure S1: Sterculic acid induces cell death at high dose in lung cancer cells cultured in $10 \%$ serum-supplemented medium. Figure S2: Sterculic acid induces cell death at high dose in non-tumorigenic human bronchial epithelial cell line NL20. Figure S3. A549 Genes whose expression was not modified after SA treatments. Figure S4. H1299 Genes whose expression was not modified after SA treatments. Figure S5. Expression of a broad panel of genes associated to EMT in A549 after SA treatments. Figure S6. Expression of a broad panel of genes associated to EMT in H1299 after SA treatments. Figure S7. Original western-blots.

Author Contributions: Conceptualization was designed by R.P. and I.M.L.; methodology, R.P.; software, Á.P.-S.; validation, R.O., A.P., Á.V.-M.; formal analysis, I.M.L.; investigation, R.P., R.O., A.P., Á.V.-M.; resources, I.M.L.; data curation, R.P. and I.M.L.; writing-original draft preparation, R.P. and I.M.L.; writing-review and editing, R.O., A.P., R.P. and I.M.L.; visualization, R.P.; supervision, I.M.L.; project administration, I.M.L.; funding acquisition, I.M.L. All authors have read and agreed to the published version of the manuscript.

Funding: This research was funded in part by a grant (PI19/01805) from the Instituto de Salud Carlos III, co-funded by the European Regional Development Fund (ERDF) "A way to build Europe" and by the Fundación Rioja Salud. I.M.L. is supported by a Miguel Servet contract (CPII20/00029) from the Instituto de Salud Carlos III, co-funded by the European Social Fund (ESF) "Investing in your future".

Institutional Review Board Statement: Not applicable.

Informed Consent Statement: Not applicable.

Data Availability Statement: Not applicable. 
Conflicts of Interest: I.M.L. holds a patent on "Methods of treatment using sterculic acid". The funders had no role in the design of the study; in the collection, analyses, or interpretation of data; in the writing of the manuscript, or in the decision to publish the results.

\section{References}

1. Quail, D.F.; Joyce, J.A. Microenvironmental regulation of tumor progression and metastasis. Nat. Med. 2013, $19,1423-1437$. [CrossRef] [PubMed]

2. Najafi, M.; Farhood, B.; Mortezaee, K. Extracellular matrix (ECM) stiffness and degradation as cancer drivers. J. Cell. Biochem. 2018, 120, 2782-2790. [CrossRef]

3. Hanahan, D.; Coussens, L.M. Accessories to the Crime: Functions of Cells Recruited to the Tumor Microenvironment. Cancer Cell 2012, 21, 309-322. [CrossRef] [PubMed]

4. Chen, C.; Hou, J.; Yu, S.; Li, W.; Wang, X.; Sun, H.; Qin, T.; Claret, F.X.; Guo, H.; Liu, Z. Role of cancer-associated fibroblasts in the resistance to antitumor therapy, and their potential therapeutic mecha-nisms in non-small cell lung cancer. Oncol. Lett. 2021, 21, 413. [CrossRef] [PubMed]

5. Hui, L.; Chen, Y. Tumor microenvironment: Sanctuary of the devil. Cancer Lett. 2015, 368, 7-13. [CrossRef]

6. Mouw, J.K.; Ou, G.; Weaver, V.M. Extracellular matrix assembly: A multiscale deconstruction. Nat. Rev. Mol. Cell Biol. 2014, 15, 771-785. [CrossRef]

7. Theocharis, A.D.; Skandalis, S.S.; Gialeli, C.; Karamanos, N.K. Extracellular matrix structure. Adv. Drug Deliv. Rev. 2015, 97, 4-27. [CrossRef]

8. McKee, T.J.; Perlman, G.; Morris, M.; Komarova, S.V. Extracellular matrix composition of connective tissues: A systematic review and meta-analysis. Sci. Rep. 2019, 9, 10542. [CrossRef] [PubMed]

9. Duval, K.; Grover, H.; Han, L.-H.; Mou, Y.; Pegoraro, A.F.; Fredberg, J.; Chen, Z. Modeling Physiological Events in 2D vs. 3D Cell Culture. Physiology 2017, 32, 266-277. [CrossRef]

10. Afik, R.; Zigmond, E.; Vugman, M.; Klepfish, M.; Shimshoni, E.; Pasmanik-Chor, M.; Shenoy, A.; Bassat, E.; Halpern, Z.; Geiger, T.; et al. Tumor macrophages are pivotal constructors of tumor collagenous matrix. J. Exp. Med. 2016, 213, 2315-2331. [CrossRef] [PubMed]

11. Sekiya, S.; Miura, S.; Matsuda-Ito, K.; Suzuki, A. Myofibroblasts Derived from Hepatic Progenitor Cells Create the Tumor Microenvironment. Stem Cell Rep. 2016, 7, 1130-1139. [CrossRef]

12. Nallanthighal, S.; Heiserman, J.P.; Cheon, D.-J. The Role of the Extracellular Matrix in Cancer Stemness. Front. Cell Dev. Biol. 2019, 7, 86. [CrossRef] [PubMed]

13. Kim, S.-H.; Turnbull, J.; Guimond, S. Extracellular matrix and cell signalling: The dynamic cooperation of integrin, proteoglycan and growth factor receptor. J. Endocrinol. 2011, 209, 139-151. [CrossRef] [PubMed]

14. Zeng, Y. Endothelial glycocalyx as a critical signalling platform integrating the extracellular haemodynamic forces and chemical signalling. J. Cell. Mol. Med. 2017, 21, 1457-1462. [CrossRef] [PubMed]

15. Wei, J.; Hu, M.; Huang, K.; Lin, S.; Du, H. Roles of Proteoglycans and Glycosaminoglycans in Cancer Development and Progression. Int. J. Mol. Sci. 2020, 21, 5983. [CrossRef] [PubMed]

16. Lu, P.; Weaver, V.M.; Werb, Z. The extracellular matrix: A dynamic niche in cancer progression. J. Cell Biol. 2012, 196, 395-406. [CrossRef]

17. Wu, Y.H.; Huang, Y.F.; Chang, T.H.; Chen, C.C.; Wu, P.Y.; Huang, S.C.; Chou, C.Y. COL11A1 activates cancer-associated fibroblasts by modulating TGF-beta3 through the NF-kappaB/IGFBP2 axis in ovarian cancer cells. Oncogene 2021, 40, 4503-4519. [CrossRef]

18. Frantz, C.; Stewart, K.M.; Weaver, V.M. The extracellular matrix at a glance. J. Cell Sci. 2010, 123, 4195-4200. [CrossRef]

19. Netti, P.A.; Berk, D.A.; Swartz, M.A.; Grodzinsky, A.J.; Jain, R.K. Role of extracellular matrix assembly in interstitial transport in solid tumors. Cancer Res. 2000, 60, 2497-2503.

20. Bourboulia, D.; Stetler-Stevenson, W.G. Matrix metalloproteinases (MMPs) and tissue inhibitors of metalloproteinases (TIMPs): Positive and negative regulators in tumor cell adhesion. Semin. Cancer Biol. 2010, 20, 161-168. [CrossRef]

21. Aued-Pimentel, S.; Lago, J.H.G.; Chaves, M.H.; Kumagai, E.E. Evaluation of a methylation procedure to determine cyclopropenoids fatty acids from Sterculia striata St. Hil. Et Nauds seed oil. J. Chromatogr. A 2004, 1054, 235-239. [CrossRef]

22. Bichi, E.; Toral, P.G.; Hervás, G.; Frutos, P.; Gómez-Cortés, P.; Juárez, M.; De la Fuente, M.A. Inhibition of 9-desaturase activity with sterculic acid: Effect on the endogenous synthesis of cis-9 18:1 and cis-9, trans-11 18:2 in dairy sheep. J. Dairy Sci. 2012, 95, 5242-5252. [CrossRef]

23. Ortinau, L.C.; Nickelson, K.J.; Stromsdorfer, K.L.; Naik, C.Y.; Pickering, R.T.; Haynes, R.A.; Fritsche, K.L.; Perfield, J.W. Sterculic Oil, a natural inhibitor of SCD1, improves the metabolic state of obese OLETF rats. Obesity 2013, 21, 344-352. [CrossRef] [PubMed]

24. Kadegowda, A.K.G.; Burns, T.A.; Pratt, S.L.; Duckett, S.K. Inhibition of stearoyl-CoA desaturase 1 reduces lipogenesis in primary bovine adipocytes. Lipids 2013, 48, 967-976. [CrossRef]

25. Gomez, F.E.; Bauman, D.E.; Ntambi, J.M.; Fox, B.G. Effects of sterculic acid on stearoyl-CoA desaturase in differentiating 3T3-L1 adipocytes. Biochem. Biophys. Res. Commun. 2003, 300, 316-326. [CrossRef]

26. Herrera-Meza, M.S.; Mendoza-Lopez, M.R.; Garcia-Barradas, O.; Sanchez-Otero, M.G.; Silva-Hernández, E.R.; Angulo, J.O.; OliartRos, R.M. Dietary anhydrous milk fat naturally enriched with conjugated linoleic acid and vaccenic acid modify cardiovascular risk biomarkers in spontaneously hypertensive rats. Int. J. Food Sci. Nutr. 2013, 64, 575-586. [CrossRef]

27. Ortinau, L.C.; Pickering, R.T.; Nickelson, K.J.; Stromsdorfer, K.L.; Naik, C.Y.; Haynes, R.A.; Bauman, D.E.; Rector, R.S.; Fritsche, K.L.; Perfield, J.W. Sterculic Oil, a Natural SCD1 Inhibitor, Improves Glucose Tolerance in Obese ob/ob Mice. ISRN Endocrinol. 2012, 2012, 947323. [CrossRef] [PubMed] 
28. Peláez, R.; Pariente, A.; Pérez-Sala, Á.; Larráyoz, I.M. Sterculic Acid: The Mechanisms of Action beyond Stearoyl-CoA Desaturase Inhibition and Therapeutic Oppor-tunities in Human Diseases. Cells 2020, 9, 140. [CrossRef] [PubMed]

29. Galbraith, L.; Leung, H.Y.; Ahmad, I. Lipid pathway deregulation in advanced prostate cancer. Pharmacol. Res. 2018, 131, 177-184. [CrossRef] [PubMed]

30. Fritz, V.; Benfodda, Z.; Rodier, G.; Henriquet, C.; Iborra, F.; Avancès, C.; Allory, Y.; de la Taille, A.; Culine, S.; Blancou, H.; et al. Abrogation of de novo lipogenesis by stearoyl-CoA desaturase 1 inhibition interferes with oncogenic signaling and blocks prostate cancer progression in mice. Mol. Cancer Ther. 2010, 9, 1740-1754. [CrossRef]

31. Tracz-Gaszewska, Z.; Dobrzyn, P. Stearoyl-CoA Desaturase 1 as a Therapeutic Target for the Treatment of Cancer. Cancers 2019, 11, 948. [CrossRef]

32. Huang, J.-D.; Amaral, J.; Lee, J.W.; Larrayoz, I.; Rodriguez, I.R. Sterculic acid antagonizes 7-ketocholesterol-mediated inflammation and inhibits choroidal neovascularization. Biochim. Biophys. Acta (BBA)-Mol. Cell Biol. Lipids 2012, 1821, 637-646. [CrossRef]

33. Major, C.A.; Ryan, K.; Bennett, A.; Lock, A.L.; Bauman, D.E.; Salter, A. Inhibition of stearoyl CoA desaturase activity induces hypercholesterolemia in the cholesterol-fed hamster. J. Lipid Res. 2008, 49, 1456-1465. [CrossRef]

34. Huang, J.-D.; Amaral, J.; Lee, J.W.; Rodriguez, I.R. 7-Ketocholesterol-Induced Inflammation Signals Mostly through the TLR4 Receptor Both In Vitro and In Vivo. PLoS ONE 2014, 9, e100985. [CrossRef] [PubMed]

35. Pariente, A.; Pérez-Sala, Á.; Ochoa, R.; Peláez, R.; Larráyoz, I.M. Genome-Wide Transcriptomic Analysis Identifies Pathways Regulated by Sterculic Acid in Retinal Pigmented Epithelium Cells. Cells 2020, 9, 1187. [CrossRef] [PubMed]

36. Coderch, C.; de Cerio, M.D.; Zapico, J.M.; Peláez, R.; Larrayoz, I.; Ramos, A.; Martínez, A.; de Pascual-Teresa, B. In silico identification and in vivo characterization of small molecule therapeutic hypothermia mimetics. Bioorg. Med. Chem. 2017, 25, 6597-6604. [CrossRef] [PubMed]

37. Scaglia, N.; Igal, R.A. Inhibition of Stearoyl-CoA Desaturase 1 expression in human lung adenocarcinoma cells impairs tumorigenesis. Int. J. Oncol. 2008, 33, 839-850.

38. Hess, D.; Chisholm, J.W.; Igal, R.A. Inhibition of StearoylCoA Desaturase Activity Blocks Cell Cycle Progression and Induces Programmed Cell Death in Lung Cancer Cells. PLoS ONE 2010, 5, e11394. [CrossRef] [PubMed]

39. Roongta, U.V.; Pabalan, J.G.; Wang, X.; Ryseck, R.P.; Fargnoli, J.; Henley, B.J.; Yang, W.-P.; Zhu, J.; Madireddi, M.T.; Lawrence, R.M.; et al. Cancer cell dependence on unsaturated fatty acids implicates stearoyl-CoA desaturase as a target for cancer therapy. Mol. Cancer Res. 2011, 9, 1551-1561. [CrossRef]

40. Tang, D.; Kang, R.; Berghe, T.V.; Vandenabeele, P.; Kroemer, G. The molecular machinery of regulated cell death. Cell Res. 2019, 29, 347-364. [CrossRef]

41. Xu, T.; Ding, W.; Ji, X.; Ao, X.; Liu, Y.; Yu, W.; Wang, J. Molecular mechanisms of ferroptosis and its role in cancer therapy. J. Cell. Mol. Med. 2019, 23, 4900-4912. [CrossRef] [PubMed]

42. Nury, T.; Zarrouk, A.; Mackrill, J.J.; Samadi, M.; Durand, P.; Riedinger, J.M.; Doria, M.; Vejux, A.; Limage, E.; Delmas, D.; et al. Induction of oxiapoptophagy on $158 \mathrm{~N}$ murine oligodendrocytes treated by 7-ketocholesterol-, 7beta-hydroxycholesterol-, or 24(S)-hydroxycholesterol: Protective effects of alpha-tocopherol and docosahexaenoic acid (DHA.; C22:6 n-3). Steroids 2015, 99, 194-203. [CrossRef] [PubMed]

43. Sun, Y.; Deng, R.; Zhang, C. Erastin induces apoptotic and ferroptotic cell death by inducing ROS accumulation by causing mitochondrial dysfunction in gastric cancer cell HGC-27. Mol. Med. Rep. 2020, 22, 2826-2832. [CrossRef]

44. Bhattacharya, D.; Basta, B.; Mato, J.M.; Craig, A.; Fernández-Ramos, D.; Lopitz-Otsoa, F.; Tsvirkun, D.; Hayardeny, L.; Chandar, V.; Schwartz, R.E.; et al. Aramchol downregulates stearoyl CoA-desaturase 1 in hepatic stellate cells to attenuate cellular fibro-genesis. JHEP Rep. 2021, 3, 100237. [CrossRef]

45. He, Y.; Liu, R.; Yang, M.; Bi, W.; Zhou, L.; Zhang, S.; Jin, J.; Liang, X.; Zhang, P. Identification of VWF as a Novel Biomarker in Lung Adenocarcinoma by Comprehensive Analysis. Front. Oncol. 2021, 11, 1-11. [CrossRef]

46. Wang, J.; Song, J.; Gao, Z.; Huo, X.; Zhang, Y.; Wang, W.; Qi, J.; Zheng, S. Analysis of gene expression profiles of non-small cell lung cancer at different stages reveals significantly altered biological functions and candidate genes. Oncol. Rep. 2017, 37, 1736-1746. [CrossRef]

47. Beaulieu, M.-E.; Jauset, T.; Massó-Vallés, D.; Martínez-Martín, S.; Rahl, P.; Maltais, L.; Zacarias-Fluck, M.F.; Casacuberta-Serra, S.; Del Pozo, E.S.; Fiore, C.; et al. Intrinsic cell-penetrating activity propels Omomyc from proof of concept to viable anti-MYC therapy. Sci. Transl. Med. 2019, 11, eaar5012. [CrossRef]

48. Godar, S.; Ince, T.A.; Bell, G.W.; Feldser, D.; Donaher, J.L.; Bergh, J.; Liu, A.; Miu, K.; Watnick, R.S.; Reinhardt, F.; et al. Growth-Inhibitory and Tumor-Suppressive Functions of p53 Depend on Its Repression of CD44 Expression. Cell 2008, 134, 62-73. [CrossRef]

49. Sottile, J.; Hocking, D.C. Fibronectin Polymerization Regulates the Composition and Stability of Extracellular Matrix Fibrils and Cell-Matrix Adhesions. Mol. Biol. Cell 2002, 13, 3546-3559. [CrossRef] [PubMed]

50. Musiime, M.; Chang, J.; Hansen, U.; Kadler, K.; Zeltz, C.; Gullberg, D. Collagen Assembly at the Cell Surface: Dogmas Revisited. Cells 2021, 10, 662. [CrossRef]

51. Zeisberg, M.; Neilson, E.G. Biomarkers for epithelial-mesenchymal transitions. J. Clin. Investig. 2009, 119, 1429-1437. [CrossRef]

52. Rybak, J.-N.; Roesli, C.; Kaspar, M.; Villa, A.; Neri, D. The Extra-domain A of Fibronectin Is a Vascular Marker of Solid Tumors and Metastases. Cancer Res. 2007, 67, 10948-10957. [CrossRef]

53. Bae, Y.K.; Kim, A.; Kim, M.K.; Choi, J.E.; Kang, S.H.; Lee, S.J. Fibronectin expression in carcinoma cells correlates with tumor aggressiveness and poor clinical outcome in patients with invasive breast cancer. Hum. Pathol. 2013, 44, 2028-2037. [CrossRef] 
54. Jun, B.H.; Guo, T.; Libring, S.; Chanda, M.K.; Paez, J.S.; Shinde, A.; Wendt, M.K.; Vlachos, P.P.; Solorio, L. Fibronectin-Expressing Mesenchymal Tumor Cells Promote Breast Cancer Metastasis. Cancers 2020, 12, 2553. [CrossRef]

55. Roovers, K.; Assoian, R.K. Integrating the MAP kinase signal into the G1 phase cell cycle machinery. Bioessays 2000, 22, 818-826. [CrossRef]

56. Balanis, N.; Wendt, M.; Schiemann, B.J.; Wang, Z.; Schiemann, W.P.; Carlin, C.R. Epithelial to Mesenchymal Transition Promotes Breast Cancer Progression via a Fibronectin-dependent STAT3 Signaling Pathway. J. Biol. Chem. 2013, 288, 17954-17967. [CrossRef]

57. Liu, J.; Tan, Y.; Zhang, H.; Zhang, Y.; Xu, P.; Chen, J.; Poh, Y.-C.; Tang, K.; Wang, N.; Huang, B. Soft fibrin gels promote selection and growth of tumorigenic cells. Nat. Mater. 2012, 11, 734-741. [CrossRef] [PubMed]

58. Peláez, R.; Morales, X.; Salvo, E.; Garasa, S.; Ortiz de Solórzano, C.; Martínez, A.; Larrayoz, I.M.; Rouzat, A. beta3 integrin expression is required for invadopodia-mediated ECM degradation in lung carcinoma cells. PLoS ONE 2017, 12, e0181579. [CrossRef] [PubMed]

59. Salvo, E.; Garasa, S.; Dotor, J.; Morales, X.; Peláez, R.; Altevogt, P.; Rouzaut, A. Combined targeting of TGF-beta1 and integrin beta3 impairs lymph node metastasis in a mouse model of non-small-cell lung cancer. Mol. Cancer 2014, 13, 112. [CrossRef] [PubMed]

60. Park, K.Y.; Kim, J. Cyclic pentapeptide cRGDfK enhances the inhibitory effect of sunitinib on TGF-beta1-induced epitheli-al-tomesenchymal transition in human non-small cell lung cancer cells. PLOS ONE 2020, 15, e0232917.

61. Zhu, C.; Kong, Z.; Wang, B.; Cheng, W.; Wu, A.; Meng, X. ITGB3/CD61: A hub modulator and target in the tumor microenvironment. Am. J. Transl. Res. 2019, 11, 7195-7208.

62. Kariya, Y.; Oyama, M.; Suzuki, T.; Kariya, Y. alphavbeta3 Integrin induces partial EMT independent of TGF-beta signaling. Commun. Biol. 2021, 4, 490. [CrossRef] [PubMed]

63. Baciu, P.C.; Suleiman, E.A.; Deryugina, E.I.; Strongin, A.Y. Membrane type-1 matrix metalloproteinase (MT1-MMP) processing of pro-alphav integrin regulates cross-talk between alphavbeta3 and alpha2beta1 integrins in breast carcinoma cells. Exp. Cell Res. 2003, 291, 167-175. [CrossRef]

64. Yosef, G.; Arkadash, V.; Papo, N. Targeting the MMP-14/MMP-2/integrin alphavbeta3 axis with multispecific N-TIMP2-based antagonists for cancer therapy. J. Biol. Chem. 2018, 293, 13310-13326. [CrossRef] [PubMed]

65. Eto, K.; Huet, C.; Tarui, T.; Kupriyanov, S.; Liu, H.Z.; Puzon-McLaughlin, W.; Zhang, X.-P.; Sheppard, D.; Engvall, E.; Takada, Y. Functional classification of ADAMs based on a conserved motif for binding to integrin alpha 9beta 1: Implications for sperm-egg binding and other cell interactions. J. Biol. Chem. 2002, 277, 17804-17810. [CrossRef]

66. Xiang, B.; Liu, Y.; Zhao, W.; Zhao, H.; Yu, H. Extracellular calcium regulates the adhesion and migration of osteoclasts via integrin alphav beta 3/Rho A/Cytoskeleton signaling. Cell Biol. Int. 2019, 43, 1125-1136. [CrossRef] [PubMed]

67. Qi, J.H.; Anand-Apte, B. Tissue inhibitor of metalloproteinase-3 (TIMP3) promotes endothelial apoptosis via a caspa-seindependent mechanism. Apoptosis 2015, 20, 523-534. [CrossRef]

68. Ioannidis, D.; Tsagkovits, A.; Rokade, A. Minimising aerosol spread during endoscopic sinus and skull base surgery. Experimental model evaluation of the efficacy of the microscope drape method. J. Laryngol. Otol. 2020, 134, 1-7. [CrossRef]

69. Xu, C.; Hou, Z.; Zhan, P.; Zhao, W.; Chang, C.; Zou, J.; Hu, H.; Zhang, Y.; Yao, X.; Yu, L.; et al. EZH2 regulates cancer cell migration through repressing TIMP-3 in non-small cell lung cancer. Med. Oncol. 2013, 30, 1-8. [CrossRef] [PubMed]

70. Ricono, J.M.; Huang, M.; Barnes, L.A.; Lau, S.K.; Weis, S.M.; Schlaepfer, D.D.; Hanks, S.K.; Cheresh, D.A. Specific cross-talk between epidermal growth factor receptor and integrin alphavbeta5 promotes carcinoma cell invasion and metastasis. Cancer Res. 2009, 69, 1383-1391. [CrossRef]

71. Cheuk, I.W.-Y.; Siu, M.T.; Ho, J.C.-W.; Chen, J.; Shin, V.Y.; Kwong, A. ITGAV targeting as a therapeutic approach for treatment of metastatic breast cancer. Am. J. Cancer Res. 2020, 10, 211-223.

72. Knyazev, E.N.; Nyushko, K.M.; Alekseev, B.Y.; Samatov, T.R.; Shkurnikov, M.Y. Suppression of ITGB4 Gene Expression in PC-3 Cells with Short Interfering RNA Induces Changes in the Expression of beta-Integrins Associated with RGD-Receptors. Bull. Exp. Biol. Med. 2015, 159, 541-545. [CrossRef]

73. Drake, J.M.; Barnes, J.M.; Madsen, J.M.; Domann, F.E.; Stipp, C.S.; Henry, M.D. ZEB1 coordinately regulates laminin-332 and \{beta\}4 integrin expression altering the invasive phenotype of prostate cancer cells. J. Biol. Chem. 2010, 285, 33940-33948. [CrossRef] [PubMed]

74. Reynolds, A.R.; Reynolds, L.E.; Nagel, T.E.; Lively, J.C.; Robinson, S.D.; Hicklin, D.J.; Bodary, S.C.; Hodivala-Dilke, K.M. Elevated Flk1 (vascular endothelial growth factor receptor 2) signaling mediates enhanced angiogenesis in beta3-integrin-deficient mice. Cancer Res. 2004, 64, 8643-8650. [CrossRef] [PubMed]

75. Reynolds, L.E.; Wyder, L.; Lively, J.C.; Taverna, D.; Robinson, S.D.; Huang, X.; Sheppard, D.; Hynes, R.O.; Hodivala-Dike, K.M. Enhanced pathological angiogenesis in mice lacking beta3 integrin or beta3 and beta5 integrins. Nat. Med. 2002, 8, 27-34. [CrossRef]

76. Aleckovic, M.; Wei, Y.; Leroy, G.; Sidoli, S.; Liu, D.D.; Garcia, B.A.; Kang, Y. Identification of Nidogen 1 as a lung metastasis protein through secretome analysis. Genes Dev. 2017, 31, 1439-1455. [CrossRef]

77. Xu, X.; Zhou, X.; Gao, C.; Cui, Y. Hsa_circ_0018818 knockdown suppresses tumorigenesis in non-small cell lung cancer by sponging miR-767-3p. Aging 2020, 12, 7774-7785. [CrossRef] [PubMed]

78. Mohan, A.; Rajan, R.R.; Mohan, G.; Puthenveettil, P.K.; Maliekal, T.T. Markers and Reporters to Reveal the Hierarchy in Heterogeneous Cancer Stem Cells. Front. Cell Dev. Biol. 2021, 9, 1-19. [CrossRef]

79. Li, L.; Qi, L.; Liang, Z.; Song, W.; Liu, Y.; Wang, Y.; Sun, B.; Zhang, B.; Cao, W. Transforming growth factor-beta1 induces EMT by the transactivation of epidermal growth factor signaling through HA/CD44 in lung and breast cancer cells. Int. J. Mol. Med. 2015, 36, 113-122. [CrossRef] [PubMed] 
80. Yadav, A.; Kumar, B.; Datta, J.; Teknos, T.N.; Kumar, P. IL-6 Promotes Head and Neck Tumor Metastasis by Inducing EpithelialMesenchymal Transition via the JAK-STAT3-SNAIL Signaling Pathway. Mol. Cancer Res. 2011, 9, 1658-1667. [CrossRef] [PubMed]

81. Bihl, M.; Tamm, M.; Nauck, M.; Wieland, H.; Perruchoud, A.P.; Roth, M. Proliferation of Human Non-Small-Cell Lung Cancer Cell Lines: Role of Interleukin-6. Am. J. Respir. Cell Mol. Biol. 1998, 19, 606-612. [CrossRef]

82. Zhang, L.; Chen, W.X.; Li, L.L.; Cao, Y.Z.; Geng, Y.D.; Feng, X.J. Paeonol Suppresses Proliferation and Motility of Non-Small-Cell Lung Cancer Cells by Disrupting STAT3/NF-kappaB Signaling. Front. Pharmacol. 2020, 11, 572616. [CrossRef]

83. Shen, Y.; Chen, Q.; Li, L. Endostar regulates EMT, migration and invasion of lung cancer cells through the HGF-Met pathway. Mol. Cell. Probes 2019, 45, 57-64. [CrossRef] [PubMed]

84. Wu, T.C.; Chan, S.T.; Chang, C.N.; Yu, P.S.; Chuang, C.H.; Yeh, S.L. Quercetin and chrysin inhibit nickel-induced invasion and migration by downregulation of TLR4/NF-kappaB signaling in A549cells. Chem. Biol. Interact. 2018, 292, 101-109. [CrossRef] [PubMed]

85. Li, D.; Jin, Y.; Sun, Y.; Lei, J.; Liu, C. Knockdown of toll-like receptor 4 inhibits human NSCLC cancer cell growth and inflammatory cytokine secretion in vitro and in vivo. Int. J. Oncol. 2014, 45, 813-821. [CrossRef]

86. Hirano, T. IL-6 in inflammation, autoimmunity and cancer. Int. Immunol. 2021, 33, 127-148. [CrossRef]

87. Rose-John, S. The Soluble Interleukin 6 Receptor: Advanced Therapeutic Options in Inflammation. Clin. Pharmacol. Ther. 2017, 102, 591-598. [CrossRef] [PubMed]

88. Amour, A.; Slocombe, P.M.; Webster, A.; Butler, M.; Knight, C.; Smith, B.J.; Stephens, P.E.; Shelley, C.; Hutton, M.; Knauper, V.; et al. TNF- $\alpha$ converting enzyme (TACE) is inhibited by TIMP-3. FEBS Lett. 1998, 435, 39-44. [CrossRef]

89. Xu, T.; Shen, X.; Seyfert, H.-M. Stearoyl-CoA desaturase 1 expression is downregulated in liver and udder during E. coli mastitis through enhanced expression of repressive C/EBP factors and reduced expression of the inducer SREBP1A. BMC Mol. Biol. 2016, 17, 1-16. [CrossRef]

90. Angelucci, C.; D’Alessio, A.; Iacopino, F.; Proietti, G.; Di Leone, A.; Masetti, R.; Sica, G. Pivotal role of human stearoyl-CoA desaturases (SCD1 and 5) in breast cancer progression: Oleic acid-based effect of SCD1 on cell migration and a novel pro-cell survival role for SCD5. Oncotarget 2018, 9, 24364-24380. [CrossRef]

91. Ran, H.; Zhu, Y.; Deng, R.; Zhang, Q.; Liu, X.; Feng, M.; Zhong, J.; Lin, S.; Tong, X.; Su, Q. Stearoyl-CoA desaturase-1 promotes colorectal cancer metastasis in response to glucose by suppressing PTEN. J. Exp. Clin. Cancer Res. 2018, 37, 54. [CrossRef]

92. Brabletz, T.; Kalluri, R.; Nieto, M.A.; Weinberg, R.A. EMT in cancer. Nat. Rev. Cancer 2018, 18, 128-134. [CrossRef] [PubMed]

93. Pan, T.; Zhang, F.; Li, F.; Gao, X.; Li, Z.; Li, X.; Ren, X. Shikonin blocks human lung adenocarcinoma cell migration and invasion in the inflammatory microenvironment via the IL-6/STAT3 signaling pathway. Oncol. Rep. 2020, 44, 1049-1063. [CrossRef] [PubMed]

94. Shen, K.-H.; Hung, J.-H.; Liao, Y.-C.; Tsai, S.-T.; Wu, M.-J.; Chen, P.-S. Sinomenine Inhibits Migration and Invasion of Human Lung Cancer Cell through Downregulating Expression of miR-21 and MMPs. Int. J. Mol. Sci. 2020, 21, 3080. [CrossRef]

95. Mauvoisin, D.; Charfi, C.; Lounis, A.M.; Rassart, E.; Mounier, C. Decreasing stearoyl-CoA desaturase-1 expression inhibits beta-catenin signaling in breast cancer cells. Cancer Sci. 2013, 104, 36-42. [CrossRef]

96. Park, S.-M.; Gaur, A.B.; Lengyel, E.; Peter, M.E. The miR-200 family determines the epithelial phenotype of cancer cells by targeting the E-cadherin repressors ZEB1 and ZEB2. Genes Dev. 2008, 22, 894-907. [CrossRef] [PubMed]

97. Yankaskas, C.; Thompson, K.N.; Paul, C.D.; Vitolo, M.I.; Mistriotis, P.; Mahendra, A.; Bajpai, V.K.; Shea, D.J.; Manto, K.M.; Chai, A.C.; et al. A microfluidic assay for the quantification of the metastatic propensity of breast cancer specimens. Nat. Biomed. Eng. 2019, 3, 452-465. [CrossRef] [PubMed]

98. Chen, Y.C.; Humphries, B.; Brien, R.; Gibbons, A.E.; Chen, Y.T.; Qyli, T.; Haley, H.R.; Pirone, M.E.; Chiang, B.; Xiao, A. Functional Isolation of Tumor-Initiating Cells using Microfluidic-Based Migration Identifies Phosphatidylserine Decarboxylase as a Key Regulator. Sci. Rep. 2018, 8, 244. [CrossRef]

99. Marin-Bejar, O.; Rogiers, A.; Dewaele, M.; Femel, J.; Karras, P.; Pozniak, J.; Bervoets, G.; Van Raemdonck, N.; Pedri, D.; Swings, T.; et al. Evolutionary predictability of genetic versus nongenetic resistance to anticancer drugs in melanoma. Cancer Cell 2021, 39, 1135-1149.e8. [CrossRef] 